\title{
Activist Protest Spillovers into the Regulatory Domain: Theory and Evidence from the U.S. Nuclear Power Generation Industry
}

\author{
Adam R. Fremeth \\ Ivey Business School \\ University of Western Ontario \\ 1255 Western Road, London, Ontario. \\ N6G ON1. Canada \\ Email: afremeth@ivey.ca \\ Guy L. F. Holburn \\ Ivey Business School \\ University of Western Ontario \\ 1255 Western Road, London, Ontario. \\ N6G ON1. Canada \\ Email: gholburn@ivey.ca \\ Alessandro Piazza \\ Jones School of Business \\ Rice University \\ 1900 Rice Boulevard, Houston, TX 77005. \\ Email: alessandro.piazza@rice.edu
}

Forthcoming at Organization Science

\begin{abstract}
We examine how social activism - in the form of public protests against contentious business practices - can spill over into the regulatory domain, extending beyond activists' articulated goals to affect firms' regulatory outcomes in areas that are not directly targeted. We argue that firms are likely to experience broader regulatory repercussions after activist protests because public contention invites greater scrutiny of firm behavior by industry regulators, increasing the likelihood that instances of organizational non-compliance will be discovered. Protests can also cause regulators to evaluate targeted firms more negatively in regulatory assessments, especially firms with less favorable pre-existing reputations or stakeholder relations, and to tighten regulations on non-targeted issues that signal their commitment to safeguarding the public interest. We further contend that the political context within which regulatory agencies operate shapes the extent of protest spillovers: when political institutions are aligned with activist goals, and when regulators are ideologically sympathetic too, protests have a more pronounced negative impact on firms' regulatory outcomes in non-targeted domains. We find robust support for our predictions in a statistical analysis of the impact of anti-nuclear protests - which sought to block nuclear power plant development by electric utilities - on utilities' subsequent regulated financial rates of return on their assets. Our analysis contributes new insights to research on the indirect consequences for targeted organizations of social activism.
\end{abstract}

Key words: social activism, protests, spillovers, regulation, private politics Note: all authors contributed equally 
Activist pressure campaigns commonly seek to affect social and environmental change by targeting firms with demands to cease contested practices, and then threatening or using tactics such as public protests, boycotts, and lawsuits to induce compliance (de Bakker and den Hond 2007; Eesley, Decelles, and Lenox 2016). Such campaigns have been successful, for instance, in forcing corporate divestment from Burma (Soule, Swaminathan, and Tihanyi 2014), improving multinational corporations' foreign labor practices (Bartley and Child 2014), and ending workplace segregation (Luders 2006). However, despite activists' focus on articulated goals - which may or may not be achieved - anecdotal evidence and academic research suggest that the consequences for firms often extend beyond the activists' original demands: for example, in 2018 activists targeted social media company Facebook due to its involvement in the Cambridge Analytica political advertising scandal, with direct action campaigns such as Faceblock and \#DeleteFacebook urging consumers to boycott the company's services (Bever 2018; Slawson 2018). While these campaigns were focused on privacy and data protection issues, which Facebook took steps to address, the negative impacts extended to the company's reputation in the labor market, hindering its ability to recruit and retain employees (Newton 2018; Rodriguez 2019). Empirical research finds that such spillovers from activism can also affect investors, another important class of stakeholder: in a study of consumer boycott and protest campaigns against major corporations, scholars found that the stock prices of targeted firms fell relative to the market following these events, revealing heightened negative investor sentiment about future firm performance (King and Soule 2007).

These examples illustrate the indirect consequences of social protest, whereby organized opposition against contentious firm practices spills over into other domains of firm activity that are not directly targeted, irrespective of whether the activists' requests are met. This happens because firms exist at the nexus of multiple market and nonmarket institutional environments (Greenwood et al. 2011), making firms' performance and access to resources dependent on the support of myriad stakeholders. As a result, an action taken against the firm in one domain — in the case of activist protest, the public sphere-may produce cascading effects in other market and nonmarket domains as well. We argue here that one institutional domain in which firms are exposed to the indirect effects of social activism is government 
regulation, since regulatory institutions are charged with serving the public interest in a wide range of industries. Because of their public interest mandate, as well as their own legitimacy concerns (Artiach et al. 2016; Leaver, 2009), industry regulators are attuned to stakeholder perceptions of firms within their jurisdiction and to organized expressions of discontent that may signal stakeholder dissatisfaction with specific firm behaviors (Hempling 2013: 53; Miles and Bhambri 1983: 84). Protests can thus act as external cues for regulators about social opposition to firm practices (Fassiotto and Soule 2017; Lohmann 1993), especially when they occur repeatedly or are organized by reputable activist groups.

In this paper, we draw on social movement theory and nonmarket strategy research to develop a political mediation model (Amenta, Carruthers, and Zylan 1992; King 2008) of the spillover effects of activist mobilization on firm-level outcomes in the regulatory arena. Our main thesis is that when activists target contentious firm activities through protests, the negative consequences of such protests can extend to industry regulators, who become more likely to tighten their oversight and regulatory policies in nontargeted domains of firm activities. By highlighting a firm's involvement in a controversial practice, protests can trigger greater regulatory scrutiny of the firm and its management, increasing the chance of questioning other practices or uncovering instances of non-compliance in either targeted or untargeted areas within the organization, leading to regulatory penalties, costly restrictions, or disapprovals. Protests can also cause regulators, who inherently depend on public as well as political support, to seek ways to defend their reputations for protecting the public interest in the face of vocal claims about harmful firm practices; by imposing penalties or ratcheting up the stringency of regulations, particularly on dimensions that are broadly salient for the public, they can pre-empt or deflect criticism from stakeholders of being 'captured' by the industry. We argue further that the spillover impact of activist protests on firm-level regulatory outcomes is moderated by firm-specific factors, including the strength of a firm's pre-existing reputation with regulators and its history of prior accommodation of activist demands. Firms with stronger reputations and activist relations are less likely to be perceived negatively by regulators in the wake of protest events, partially insulating them against enhanced regulatory scrutiny. Additionally, we hypothesize that political conditions affect the sensitivity of regulators to protests against contentious practices: ideological alignment 
between elected politicians, regulators and activists augments the negative effect of protests, contributing to an even less favorable regulatory environment for firms.

We test our predictions in the context of the U.S. nuclear power generation sector, where for several decades activists have pursued the goal of halting new nuclear development by electric utility firms. During the 1970s and 1980s, anti-nuclear activists staged hundreds of protests across the country (Fuller 1975; Rucht 1990; Wellock 1998). While protests were primarily aimed at utilities' activities in nuclear power generation — especially the development and construction of proposed nuclear power plants (Giugni 2004; Piazza and Perretti 2015, 2020; Walsh 1981) —we examine whether they also influenced policy decisions of electricity sector industry regulators who establish the regulated financial rate of return (ROR) that utilities are permitted to earn on their assets. Under the rate of return method of regulation used in the sector (Lesser 2002), the ROR is a core and publicly visible determinant of the consumer rates that utilities are ultimately permitted to charge (Goodman 1998: 573). While legal precedent requires that regulators set the ROR at a 'fair' level (Welch 1968: 478), regulators have discretion to set RORs that are more or less generous (Fremeth and Holburn 2009; Joskow 1974), creating the risk for utilities that protests against nuclear power - which may damage the firm's standing in the eyes of the regulator - will adversely affect regulators' decisions on the allowed ROR. This empirical setting therefore provides a unique opportunity to explore whether social activism in the form of anti-nuclear protests spills over into firms' regulatory outcomes that were not central to activists' articulated goals.

Using archival sources, we construct a complete panel dataset of regulatory agency decisions on the regulated financial rate of return, which varies by firm and over time, for each firm in the population of 206 electric utilities for the 26-year period from 1970 to 1995 . In a statistical analysis that accounts for potential endogeneity of protests and unobserved time-invariant firm heterogeneity, we find that an increasing number of anti-nuclear protests occurring in close geographic proximity to utilities' proposed or operating nuclear power generation plants was associated with those firms subsequently receiving lower regulated financial rates of return. We also find evidence that protests had a smaller negative impact on the ROR for firms that had acceded to prior activist demands to halt nuclear construction and for firms that had 
achieved relatively more favorable regulatory policy decisions in previous years, which is suggestive of stronger firm relationships with external stakeholders. On the other hand, protests had a more pronounced negative impact on RORs when state governments and regulatory agencies were controlled by the Democratic party, which historically had been less supportive of nuclear power generation than the Republican party. Our empirical estimates are robust to a variety of alternative models and methods, indicating reliable support for our hypotheses. To the best of our knowledge, our analysis is the first to comprehensively study the spillover effects of social protests on firms' nonmarket outcomes in the regulatory arena, contributing new insights to research on the indirect consequences of activism.

\section{Theoretical Background}

Social activism in the public sphere. There exists a long tradition of sociological research on social movements and the conditions under which activism affects political and social change, with numerous studies of issues ranging from civil rights to organized labor, military conflict, the environment, and women's and minority rights (e.g. Amenta et al. 2010, Gamson 1975, Giugni 1998, Lammers 1969, Piven and Cloward 1977, Walker et al. 2008). Because collective action has historically been used to channel social movements' grievances against the state (Walker et al. 2008), studies of social movements have largely focused on elected political institutions as the target, and on their influence on legislative outcomes as measures of success (Aranda and Simons 2018; Gamson 1975; Kitschelt 1986). Scholars have examined the impact of social movements at distinct stages of the law-making process, i.e. agenda-setting, the production of legislative content, and legislative passage (Schneiberg and Bartley 2001; Schneiberg and Soule 2005; Soule and Olzak 2004), arguing that movements are particularly influential in the early stages - obtaining inclusion of focal issues on political agendas and shaping the content of legislative bills to increase the value of collective benefits (Amenta 2006; Soule and King 2006). By mobilizing resources and voters, and gaining the attention of the broader public through organized campaigns, social movements can leverage politicians' (re-)election motivations in order to achieve field-level policy aims, which become more attainable when the political environment is supportive of the movement's goals or when political opportunity structures facilitate social activism (Kitschelt 1986; Kriesi 1989, 2007). 
Within this body of research, some studies have also examined how social activism impacts public policy not only by shaping legislation, but also by affecting the implementation and enforcement of policy by administrative agencies. Rochon and Mazmanian (1993: 84), for example, describe how activists mobilized against hazardous waste siting proposals in the United States, "demanding to participate in negotiations on hazardous waste regulation and in the implementation of specific agreements on facility siting and operation”. Similarly, Andrews (2001) found that activists had substantial influence on how antipoverty policies were implemented in Mississippi during the Civil Rights era when they were able to secure formal representation on advisory committees for local Community Action Programs, the central funding mechanism for the 'War on Poverty'. Taken together, these studies highlight how social activists' direct involvement and voice in administrative processes can shape policy outcomes once the policymaking process reaches the implementation stage.

Complementing this sociological body of research, management and strategy scholars have begun to study social movement action targeted at corporations, which, relative to the highly formalized institutions of state government, may respond more quickly to movement demands (e.g. Eesley and Lenox 2006, Ingram et al. 2010, Julian et al. 2008, Luo et al. 2016, McDonnell and King 2013, Reid and Toffel 2009, Marquis, Toffel and Zhou 2016). By directing public attention towards contested corporate practices through organized events that voice stakeholder disapproval and inflict reputational damage, activists prompt stakeholders to re-evaluate their relationships with targeted firms, which can be sufficient to induce firm compliance with activists' demands (Bartley and Child 2014). Faced with the threat of negative performance consequences, firms have adopted a repertoire of strategies that mitigate the risk of being targeted by activists such as scaling back involvement in contested business practices (Durand and Vergne 2015; Piazza and Perretti 2015) or self-regulating (Baron, Neale, and Rao 2016; Eesley and Lenox 2006). If activist campaigns nonetheless occur, firms may attempt to contain their impact through tactics such as impression management and pro-social claims (Hiatt, Grandy, and Lee 2015; McDonnell and King 2013).

Spillover effects of social activism. While most research on the impact of social activism has examined the direct effects on targeted organizations, a few scholars have explored indirect effects on 
related organizations and stakeholders, recognizing that public pressure campaigns can have myriad intended and unintended consequences. As an example, in a study of anti-Walmart protests in local communities, Yue, Rao, and Ingram (2013) found that Target, a rival retailer to Walmart, was also deterred from locating in the same towns, a response attributable to Target's heightened concern about becoming a future activist target, despite having a more positive labor relations reputation than Walmart. Similarly, Soule et al. (2014) argued that human rights campaigns against high profile corporations such as PepsiCo, which caused the company to cease its operations in Burma, contributed to other foreign companies' decisions to divest from Burma as well. The indirect effect of activist campaigns designed to damage market opportunities for firms in targeted industries further extends to the creation of new opportunities for entrepreneurs in other sectors: for instance, the Women's Christian Temperance Union's demonization of alcohol consumption during the late $19^{\text {th }}$ century not only led to the demise of breweries but it helped to underpin the rise of soft drink manufacturers such as Coca-Cola, which were deemed more socially acceptable (Hiatt, Sine, and Tolbert 2009).

Beyond the industry field context, other scholars have focused on understanding how different stakeholders who are not the focal target of activist campaigns may nonetheless respond to a campaign's actions and communications. In this regard, some evidence suggests that investors are quite sensitive to activist campaigns directed at companies in which they have financial interests. In an analysis of protest and boycott campaigns conducted against publicly traded U.S. corporations between 1962 and 1990, King and Soule (2007) noted that even though boycotts frequently had little success in deterring consumers - the primary target of activists - they created sufficient investor uncertainty about future market opportunities that stock prices fell relative to the market, especially when boycotts attracted greater media attention. As the authors argued, activist protests "communicate dissatisfaction among stakeholders, and investors may see this dissatisfaction as a threat to a firm's reputation and legitimacy", and they convey "information suggesting that the corporate target may have difficulty maintaining its current market value" (King and Soule 2007: 417). Elected politicians also appear to be circumspect about associating with companies that have been the subject of social movement action: McDonnell and Werner (2016) found that politicians were 
more likely to return campaign contributions previously received from boycotted firms, and were less likely to invite them to testify in congressional hearings, presumably concerned about adverse reputational and electoral consequences. Further, boycotted firms were less likely to be awarded government procurement contracts by federal executive agencies.

These studies collectively suggest that activist campaigns and protests can cast a long shadow onto external stakeholders of firms targeted for their contentious practices. This research remains sparse, however, and compared to the extensive literature on the direct effects of activism, we know much less about spillover effects, particularly on nonmarket stakeholders, as well as about the environmental conditions when spillovers are more or less severe and their implications for organizational performance (Briscoe and Gupta 2016). In the next section, we extend this nascent stream of research by examining how activist campaigns levied against firms' contentious activities can spillover to a crucial stakeholder for many firms - industry regulators - and their public policy decisions on issues that are not the focal concern of activists.

\section{Hypotheses}

Protest spillovers in the regulatory domain. Industry regulators are a central nonmarket stakeholder for firms in many sectors since they operate as the 'front line' of government, issuing rules and orders that regulate firm behavior - for instance by licensing manufacturing facilities, approving new pharmaceutical drugs, or setting consumer rates for utility firms - and monitoring and enforcing compliance on a continuous basis (Bonardi, Holburn, and Vanden Bergh 2006; Hiatt and Park 2013; Macher, Mayo, and Nickerson 2011). While regulators' specific policy mandates are established in legislation, their broad goal is to ensure that firms operate in the public interest. As the Federal Communications Commission (FCC) describes its mandate, “The FCC's core mission has always been to serve the broader public interest, and that means protecting consumers and keeping the public safe" (FCC, 2018). Regulators typically interpret the public interest goal as balancing competing stakeholder demands (Goodman 1998: 33; Peltzman 1976; Stigler 1971), and they have latitude to set regulations that are more or less stringent, or that place greater weight on specific stakeholders' interests (Grandy and Hiatt 2020; Hempling 2013: 26). 
Importantly for firms, regulation - unlike legislation - is often implemented and enforced at the firm-level, meaning that regulators make decisions for individual firms that account for firm-specific issues and attributes.

In determining regulatory rules and orders, regulators draw on arguments and information provided by firms and other stakeholders in the context of formal administrative processes, but they are also sensitive to cues from their external social and political environment (Grandy and Hiatt 2020; Joskow 1974; McCubbins, Noll, and Weingast 1987). The ability of regulators to conduct their work depends in part on maintaining institutional legitimacy in the eyes of political institutions - such as legislators who determine appointments and agency resources - and of the public at large who rely on their oversight (Carpenter 2001; Hiatt and Park 2013). Losing legitimacy risks regulators having their authority constrained, budgets reduced, and individual career prospects tarnished (Niskanen 1971; Leaver 2009; Carrigan 2014). Organized activist demonstrations and protests are examples of external cues that provide signals to regulators about social opposition to contentious firm practices (Fassiotto and Soule 2017). While activist groups need not necessarily represent mainstream opinion on a contested issue, by highlighting alleged risks and harms they have the ability to negatively sway political or public sentiment, especially if protests are spearheaded by reputable or moderate organizations (Feinberg, Willer, and Kovacheff 2020; Hoffman and Bertels 2010: 62). Additionally, protests can garner attention from the media, which, whether sympathetic or not, increases public and political awareness, as well as scrutiny, of regulatory agency actions (Newig 2004). Heightened external attention thus puts the regulator's own reputation for prudent industry oversight at risk. Hence, as activists protest more vigorously against a contested firm practice for instance through more frequent or larger demonstrations - regulators become more likely to incorporate, explicitly or implicitly, activist concerns in regulatory decisions. By responding to organized stakeholder pressure in this way, regulators can limit the threat to their own legitimacy and dampen external, and potentially critical, attention.

While protests shape regulators' and other stakeholders' understandings of specific firm practices, however, their impact can spill over beyond the protesters' goals to regulators' evaluations of other 
dimensions of a firm's operations. Several mechanisms underpin regulatory spillovers. First, in response to protestors' claims about harmful effects of contentious practices, a regulator may strengthen monitoring or initiate investigations of the firm, which increases the likelihood of uncovering evidence of non-compliant practices in other operational areas, leading regulators to tighten up regulation of aspects beyond the original protest target or to impose penalties. Activist organizations that also advance evidence and compelling arguments will be more likely to solicit an oversight response from the regulator (Lyon 2010: 169). For instance, credible activist claims and information about the safety of a proposed oil pipeline in a community may prompt regulators to investigate the firm's safety record on other projects or to scrutinize a firm's internal safety routines and policies. The longer that a regulator shines a critical spotlight on a firm's activities, the greater the chance of uncovering evidence of non-compliance somewhere within the organization. ${ }^{1}$

Second, even without additional audits or scrutiny, protests about a contested practice may cause regulators to form a negative impression of the firm's management and to question the probity of organizational decision-making, particularly if protests occur repeatedly. Although protests by radical activist groups may be unavoidable, other protests by moderate groups can potentially be defused or preempted if firms adopt a proactive or conciliatory approach to managing external stakeholder relations (Henisz, Dorobantu, and Nartey 2014). Regulators will be less inclined to rule in favor of the firm in future regulatory decisions on matters not targeted by activists if they believe there are underlying cultural or behavioral tendencies within the firm that lead managers to systematically ignore or discount important stakeholders' legitimate concerns (Hiatt and Park 2013).

Third, by drawing public attention to claims of specific social harm that result from contentious activities, protests can tarnish a regulator's reputation for protecting the public interest. Research has found

\footnotetext{
${ }^{1}$ Investor Warren Buffett colorfully described the 'cockroach theory' when investigating corporations in response to a scandal: "What you find is there's never just one cockroach in the kitchen when you start looking around", as quoted by Berkeley Lovelace at https://www.cnbc.com/2017/08/30/warren-buffett-on-wells-fargo-theres-never-just-onecockroach-in-the-kitchen.html (accessed March 9, 2020).
} 
that nonmarket stakeholders such as politicians tend to disassociate themselves from "blacklisted" - i.e. protested - firms in order to protect their own reputations (McDonnell and Werner 2016). Industry regulators are also likely to seek ways to distance themselves from protested firms to avoid reputational damage: by adopting less favorable regulations - notably on regulatory issues that are widely salient - in the period after a protest they can pre-empt criticism that they are supporting or siding with self-interested corporations involved in contentious activities at the expense of other stakeholders. Regulatory policies that are not within activists' articulated goals but which are perceived to be favorable for the firm could trigger new activist claims that regulators had been 'captured' by industry interests, undermining regulators' institutional legitimacy and risking intervention by political actors. Hence, by finding opportunities to 'act tough', regulators can mitigate adverse effects on their professional standing arising from activist protests.

In sum, we predict that the negative impact of protests against contested activities can extend beyond the targeted practice, spilling over to affect regulatory treatment of other aspects of the firm's operations and performance. This leads to our first hypothesis:

HYPOTHESIS 1. A greater number of public protests targeted at a firm 's contentious activities will lead to less favorable regulatory outcomes for the firm in non-targeted domains.

Political context. Social movement scholars have argued that in addition to activists' resources and strategies, the impact of protests on policy outcomes depends on the political environment in which they occur. In this regard, the political mediation model proposes that mobilization is especially likely to produce results when institutional political actors are supportive and "see benefit in aiding the group the challenger represents" (Amenta et al. 2010: 298, 1992). Empirical analyses have found significant support for the moderating role of political conditions in accounting for movement effects, with the partisan political context being frequently cited as an important moderator (Amenta et al. 2010). While the political mediation model has been developed primarily within the context of elected legislative institutions, its logic can be extended to regulatory agencies, which are a distinct branch of government.

Regulatory agencies are generally established as independent administrative entities that operate separately from the executive and legislature, guided in their policymaking and authority by statute. 
However, although regulators have a degree of structural independence, they are not immune to political pressures since political institutions control a number of mechanisms that can be used to incentivize or corral regulators, directly or indirectly (Ewans and Garber 1988; McCubbins et al. 1987). Regulators are generally appointed for fixed terms by the executive branch with the consent of the legislature, so careeroriented regulators who wish to be re-appointed will pay heed to political views. Annual agency budgets and appropriations are also politically-determined, which represents another lever of political control (Ferejohn and Shipan 1990; Shipan 2004). Recognizing the potential for political intervention, regulators thus have an ex ante incentive to account for political preferences in their policymaking. If social movement activism against a firm is successful in gaining the sympathy of elected politicians, regulators may come under implicit or explicit political pressure to scrutinise firms involved in contentious practices and to tighten up regulations, signaling to external stakeholders that safeguarding the public interest is a priority.

Top down political pressure is more effective when there is ideological alignment between legislative and executive branches of government (Weingast and Moran, 1983). Agency appointments, budget decisions, and enactment of new legislation all require common agreement in order to be implemented. Different branches of government are more likely to agree on their approach to industry regulation if they share a common political ideology. Under a politically aligned government, regulators are likely to be especially attuned to elected politicians' responses to activist protests, recognizing the greater risk of straying too far from political views of the public interest. In a similar vein, the risk of political intervention in regulatory matters is further heightened when an aligned government's ideology is consistent with that of the activist organizations engaged in protests. By contrast, when elected political institutions are characterized by ideological divisions, regulators have greater latitude to act independently and will be less concerned about political pressure arising from activist protests. Accordingly, when government is divided across partisan lines, regulatory decision-making should be less susceptible to spillover effects from activist protests than when government is ideologically unified and sympathetic towards activist causes. Hence: 
HYPOTHESIS 2. The negative effect of public protests on a firm's regulatory outcomes in nontargeted domains will be greater when the dominant political ideology of elected political institutions is aligned with activist causes.

Regulator ideology. As with the political institutions that have oversight authority over regulatory agencies, regulators can have ideological orientations that inform their decision-making on regulatory issues (De Figueiredo and Edwards 2007). Ideological biases that favor a particular stakeholder group can enter regulatory decisions since regulators possess discretion when weighing up competing stakeholder interests. For instance, in a study of U.S. state telecommunications pricing regulation, Teske (1991) found that Republican political ideology tended to favor the interests of incumbent firms while Democratic ideology favored those of consumers and new entrants. Research has also found that Democrats generally view environmental causes and policies more favorably than do Republicans (Lyon and Yin 2010).

Building on the political mediation model, we propose that regulator political ideology is likely to moderate the spillover effect of activist protests on regulatory policies. When industry regulators are intrinsically sympathetic to the goals or positions of activists, activist strategies and tactics should be more effective since nonmarket actors are more receptive to social change under such conditions (Amenta et al., 2010). Protests can reinforce regulators' pre-existing ideological biases when evaluating policy issues: regulators will be more willing to interpret protest events as legitimate indicators of valid public concerns about the firm's actions and they will be more willing to reject counterarguments that conflict with their biases. Protests can thus trigger additional regulatory scrutiny and adoption of more stringent regulation when they confirm regulators' beliefs about the policy priorities that will safeguard the public interest. On the other hand, regulators that are ideologically at odds with the position of an activist group may hold a different interpretation of the public interest and place greater weight on the views of other stakeholders, offsetting the impact of activists. The occurrence and extent of social activism should thus have a stronger spillover effect on a firm's regulatory outcomes when there is ideological alignment between activists and regulators. Hence: 
HYPOTHESIS 3. The negative effect of public protests on a firm's regulatory outcomes in nontargeted domains will be greater when there is ideological alignment between regulators and activists.

Firm reputation with regulators. Since regulators often implement and enforce regulations at the individual firm level, the spillover extent of social protests will vary according to two salient firm characteristics that affect how regulators respond - the firm's reputation with the regulatory agency, which we discuss first, and the firm's history of accommodating activist demands. Existing studies of activism find that a firm's public reputation is an important factor that shapes campaign dynamics, including how firms respond to pressure tactics and how related stakeholders react (King 2008; Luo et al. 2016; McDonnell 2016). Firms with stronger reputations tend to be affected less by pressure campaigns - and make fewer concessions - since the firm's stakeholders are less likely to believe activist claims of social harm when they are disputed by more reputable firms (Diermeier 2011: 108). When an organization comes under fire from activists, stakeholders will "be more likely to give the benefit of the doubt to a high-reputation organization than to organizations without this asset", because "a high-reputation organization accrues a larger stock of social capital and goodwill" (Zavyalova et al. 2016: 258). In other words, in the aftermath of an adverse event such as a public protest, reputation acts as a buffer, minimizing the negative fallout among an organization's stakeholders (Park and Rogan 2019).

Applying this argument to the regulatory context, we posit that a firm's prior reputation with an industry regulator is likely to affect how the firm is perceived in the wake of activist protest. Firms in regulated industries develop reputations with regulators for operating in a manner that is consistent with the public interest based on a history of repeated firm-regulator interactions over time, during which regulators learn about a firm's organizational culture and decision-making processes (Miles and Bhambri 1983: 116; Wilson and Veuger 2017). For example, in a study of manufacturing facility inspections by the Food and Drug Administration (FDA), scholars found that some pharmaceutical firms developed poor reputations with the FDA, based on the outcomes of prior inspections, which led to increased scrutiny by the FDA, while other firms established more positive reputations (Macher et al. 2011). For firms that have 
developed a favorable reputation with the regulator, a public protest is less likely to lead the regulator to conclude that additional compliance investigations are warranted or that the firm's management practices and culture are potentially harmful to consumers, workers, or other stakeholders. As such, firms whose past interactions with regulators have yielded positive outcomes are likely to benefit from greater regulatory goodwill, which will mitigate the degree to which protests against one aspect of firm operations spill over to harm regulatory treatment of non-targeted domains. Conversely, firms with poor regulatory reputations should see the negative spillover effects of protests magnified, as regulators will be inclined to regard protests as further corroboration of their past judgments of the firm. Thus:

HYPOTHESIS 4. The negative effect of public protests on a firm 's regulatory outcomes in nontargeted domains will be greater the worse the firm's reputation with regulators.

Prior firm accommodation of activist demands. The extent of protest spillovers into regulatory outcomes is also likely to depend on whether firms' past behavior is consistent with activist demands to change their business operations and practices. While research on firm-activist campaign interactions suggests that firms frequently do not accommodate activist demands (King 2008), the ability of firms to defuse conflict and to reach agreement or compromise can signal that their business operates in the public interest and that they value cooperative relationships with external stakeholders. A track record of working productively with social movement organizations enables firms to develop a reputation for being a 'good corporate citizen' that responds to reasonable social concerns, so in the event that conflict or a protest does occur, the firm may be able to avoid additional criticism or else draw on support from other stakeholders. ${ }^{2}$

2 The example presented by Ruf et al. (2001) of Celgene Pharmaceuticals, which owned the cancer treatment drug thalidomide, describes how a firm worked with social movement organizations to diffuse opposition to the controversial drug and obtain regulatory support. After entering the FDA drug approval process for using thalidomide as a treatment for myeloma, Celgene worked with anti-thalidomide groups to develop specific recommendations for how the drug should be marketed. In some cases, Celgene exceeded the groups' demands. This allowed the firm to avoid further protests and regulatory delays not only for its thalidomide application with the FDA but also with other drugs that they sought to market. 
In turn, a firm's prior receptiveness to activist organizations' demands, and its willingness to abandon contentious practices, are likely to shape how regulators respond to protests against contested practices. Regulators will be less minded to allocate agency resources and effort to new investigations and further scrutiny of firms engaged in protested practices if their past behavior has accommodated activists' goals. In such cases, regulators may infer from a protest event that activists are in fact radical organizations whose positions are not reflective of broader public opinion, and that the firm is operating in the public interest and not systematically ignoring or discounting important stakeholders' legitimate concerns. Or they may conclude that the firm is willing to address the root causes of activist concerns and that contention will ultimately abate. Regulators will also be less concerned about protecting their own reputations from potential future criticism - by tightening up regulations and oversight - if firms are recognized as having pursued good-faith efforts to reach compromise in previous episodes of contention with activist organizations. Hence, if regulators believe, based on a firm's prior accommodation of activist demands, that a firm's operations and practices are consistent with the public interest, then activist protests are less likely to spill over into subsequent regulatory decisions in nontargeted aspects of the firm's business. Hence:

HYPOTHESIS 5. The negative effect of public protests on a firm's regulatory outcomes in nontargeted domains will be less pronounced the more accommodating the firm has been to activist demands in the past.

\section{Empirical Approach}

Industry context. We test our hypotheses about protest spillovers into the regulatory domain in the context of the U.S. electricity sector since firms in this industry are regulated by economic regulators due to their natural monopoly status. The industry has also been characterized by a strong degree of contention from social activists targeting firms' development of commercial nuclear power generation. In the early stages of the technology, which originated in the mid-1950s as an offshoot of military weapons programs, nuclear power was viewed largely as a safe and affordable energy source (Gamson and Modigliani 1989). In the following two decades the nuclear industry expanded, with hundreds of new units 
being proposed, but so too did anti-nuclear opposition, which became more organized and vociferous, reflecting growing concerns about public safety and environmental impacts. Nuclear accidents at Three Mile Island in 1979 and Chernobyl in 1986 undermined public assumptions about safety and government oversight, and brought the issue of nuclear power into the forefront of national debate (Nelkin 1981; Walker 2006; Walsh 1981, 1986). National protest movements emerged in the late 1970s (Wellock 1998) with the founding of specialized anti-nuclear groups such as the Clamshell Alliance and the Abalone Alliance. By the early 1980s, bolstered by contextual factors such as the rapid cost escalation of nuclear power plant construction (Gamson and Modigliani 1989; Komanoff 1982; Lyon and Mayo 2005), anti-nuclear activism emerged as powerful opposition for the nuclear power industry (Berndt and Aldrich 2016, Daubert and Moran 1985). Public protests against nuclear development became more frequent during the 1970s and 1980s, sometimes attracting hundreds of participants and media headline attention (Piazza and Perretti $2015,2020)$.

Political divisions also emerged in this time period. Nuclear power enjoyed bipartisan support in the late 1950s, though in the following decades the Democratic Party became increasingly opposed to it while the Republican Party maintained its support. This divergence was reflected in the national platforms of the two parties: while in 1972 the Democratic Party had advocated for greater research and development efforts in the field of nuclear power, by 1976 it was calling for dependence on nuclear power to be kept to a minimum, and by 1980 it called for nuclear power to be phased out. Conversely, the Republican Party remained a strong supporter of nuclear power ever since the Atoms for Peace program was started in 1955 by President Eisenhower, a Republican. Even after the Three Mile Island accident, Republicans remained steadfastly committed to nuclear power, with the party platform for the 1980 elections supporting "accelerated use of nuclear energy" and declaring nuclear power generation as having the "highest priority". 3

\footnotetext{
${ }^{3}$ The federal Democratic Party's 1980 platform stated “Through the federal government's commitment to renewable energy sources and energy efficiency, and as alternative fuels become available in the future, we will retire nuclear power plants in an orderly manner." The platform is available at
} 
Industry regulation. Firms in the U.S. electric utility sector are regulated by independent state regulatory agencies, Public Utility Commissions (PUCs), which set the consumer rates that electric utility firms (who have monopoly franchises) are permitted to charge. PUCs regulate utilities according to the 'rate-of-return' method of regulation (Hyman 2000: 247; Viscusi, Harrington, and Vernon 2005: 430; Welch 1968: 478), by which PUCs determine the regulated financial rate of return (ROR) that a firm is allowed to earn on its approved assets (Joskow 1974; Bonardi et al. 2006). PUCs are legally required to set a 'fair' ROR that enables a firm to attract sufficient financial capital for future investment, but this standard affords PUCs some discretionary flexibility (Goodman 1998: 128). A higher ROR rewards shareholders and can signal a regulator's endorsement of a firm's actions, acting as an incentive for future investment by the firm. Yet an increase in the ROR may also attract scrutiny and criticism by consumers due to its upward impact on consumer electricity rates. ${ }^{4}$ A lower ROR, on the other hand, penalizes shareholders and makes future investments less attractive, and may be interpreted as manifestation of regulatory disapproval of the firm's practices or strategy (Hyman and Habicht 1986). ${ }^{5}$

PUCs establish RORs in the context of periodic firm-specific rate reviews, which are administrative processes that are generally requested by firms after periods of cost growth. We provide an overview of the rate review process, including the basic steps and methods used in Appendix A. The rate review process involves public hearings where the firm, PUC staff, and intervenors present arguments and information to support their positions about the appropriate ROR (Fremeth and Holburn, 2009). At the conclusion of the

http://www.presidency.ucsb.edu/ws/index.php?pid=29607. The Republican Party's 1980 platform is available at http://www.presidency.ucsb.edu/ws/index.php?pid=25844.

${ }^{4}$ As an example, the Public Counsel in Florida publicly criticized the Florida Public Service Commission following a rate review that set the ROR for TECO Energy at $11.35 \%$ in 1993: "In its protest, Public Counsel claims that the rate of return of 11.35 percent is excessive and requests an expedited proceeding to determine a new allowed rate of return. Public Counsel also has asked the FPSC to rescind the 1994 rate increase and reduce rates prospectively" (PR Newswire, November 16, 1993, Tampa, FL).

${ }^{5}$ For example, the Maine Public Utilities Commission explicitly reduced Central Maine Power's (CMP) allowed rate of return by 75 basis points due to the firm's record of poor customer service and billing practices. In this case, the PUC stated that, "This reduction [in the ROR] is supported by substantial evidence of failures by CMP's management to provide reasonable and adequate customer service over recent years, and especially following the transition to its new billing system, which lead us to find that this service has been imprudent (Central Maine Power rate review 201800194). 
process, which can extend up to a year or more in duration, PUC commissioners make a majority decision on the regulated ROR and on other factors that are used in calculating the electricity rates that a firm is permitted to charge consumers (Hyman 2000: 263; Viscusi et al. 2005: 431).

Although PUCs are constituted as independent institutions that operate separately from legislative and executive branches of government, their decisions are not immune to external public and political pressures or criticism (Joskow 1974; Leaver 2009). First, most citizens are electricity consumers, making public opinion on energy regulation particularly salient for PUCs. PUC legitimacy in the public sphere relies on crafting regulatory policies that are deemed acceptable to a range of stakeholders and that achieve a broad level of societal support (Goodman 1998: 128; Hempling 2013: 51). Yet societal values and the meaning and interpretation of what constitutes the public interest can evolve over time, making PUCs sensitive to external cues from stakeholders about the acceptability of emerging energy issues. Second, PUCs, like other regulatory bodies, are accountable to political institutions, which control resource flows and senior bureaucratic appointments. PUCs' annual budgets and appropriations are approved by the state legislature and governor, and PUC commissioner appointments are generally made by the governor with the consent of the state Senate. ${ }^{6}$ Threats of resource cuts or of non-reappointment can be powerful tools through which state governments can encourage PUCs to adhere to their energy sector policy agendas.

Prior empirical research has found that economic variables - such as the interest rate, which affects the firm's financial cost of capital - as well as a range of external political and institutional factors including state legislature political ideology, PUC commissioner political ideology, PUC commissioner selection method, and local environmental group membership - influence PUC decisions on the allowed rate of return (Bonardi et al. 2006; Fremeth et al. 2014; Joskow, 1972; Hagerman and Ratchford 1978; Roberts, Maddala, and Enholm 1978). These factors have been used to explain variation in the ROR among firms in the U.S. electricity sector. While these and other studies (e.g. de Figueiredo and Edwards, 2007;

\footnotetext{
${ }^{6}$ PUCs are generally led by three to five commissioners who are appointed for staggered terms of five years. In 10 states PUC commissioners are elected by the citizenry but budgets and governing legislation remain under the control of the executive and legislative branches.
} 
Leaver, 2009) confirm the impact of external political forces on PUC decision-making, none to date have explored the impact of activist protests.

Sample. To test our hypotheses we compiled a panel dataset for the population of investor-owned utilities in the U.S. electricity industry, containing information on the regulated financial rate of return for each firm, the role of nuclear generation in the firm's power generation asset base, and the incidence of geographically proximate public protests against nuclear power from 1970 to $1995 .^{7}$ The dataset covers 206 firms, creating a potential sample of 5,356 firm-year observations, which is reduced to 4,351 observations due to missing values on some variables and merger and acquisition activity within the sector. The data includes decisions on the regulated rate of return for each of the 1,886 rate reviews conducted by PUCs during the sample period. Firms requested rate reviews on average approximately every three years. We identified 340 anti-nuclear protests, occurring in 36 states and the District of Columbia. The annual number of protests rose from a single protest in 1970 to a peak of 90 in 1979, and then gradually declined to a handful each year in the early 1990 s.

Variables. Our dependent variable, Rate of Return, is the percentage financial return a firm is permitted to earn on its assets as determined by the state PUC during a regulatory rate review. The ROR is a publicly visible and widely salient regulatory decision, making it a plausible regulatory outcome variable to use in testing for protest spillovers beyond activists' articulated goals. Firms' RORs exhibit variation within the industry as well as over time; for instance, in 1985, while the average Rate of Return across all firms' rate reviews that year was 11.86 percent, the maximum was 13.57 percent, and the minimum was 9.59 percent. Over our entire sample, the average Rate of Return was 9.89 percent with a standard deviation

\footnotetext{
${ }^{7}$ We focus on the period from 1970 to 1995 for two primary reasons: first, there was a significant amount of antinuclear mobilization and protest activity during this period even though many nuclear reactors were ordered in the 1960s. We conclude the study in 1995 since this was when investor-owned utilities ceased construction of any further nuclear units. The second consideration was the availability of data for our dependent variable, the regulated financial rate of return for electric utility firms. Data on utilities' regulated rates of return, which comes from regulatory documents of utilities' periodic regulatory reviews, is available for years after 1980 from several sources, specifically annual reports of the National Association of Regulatory Commissions (NARUC) and Regulatory Research Associates, a specialist consulting firm. We were able to extend our data back to 1970 through an exhaustive search of state archival sources and regulatory commissions, compiling a comprehensive dataset for each utility's regulated financial rate of return for each year from 1970 to 1995.
} 
of 1.59 percentage points. Annual summary statistics on the ROR are presented in Table A.1 of Appendix A. RORs also vary between firms in the same state. In the state of Ohio, for example, Ohio Power's ROR was set by the PUC at $11.35 \%$ in 1983 while that of Toledo Edison, another Ohio utility, was set at $12.72 \%$. Across our sample, the standard deviation of RORs among firms within the same state and year is 45 basis points.

To measure the degree of public protest against nuclear power generation - our focal independent variable - we create the variable Protests, based on the count of reported protest events within the geographic vicinity of a firm's nuclear power plant generating unit(s). Protest information was drawn from Stanford University's Dynamics of Collective Action Project database, which contains data on anti-nuclear protest events, including their dates and locations, reported in the New York Times between 1960 and 1995. To test the comprehensiveness of the New York Times coverage of protests, we compared the Stanford data to protest events reported by other local newspapers in the regions in which nuclear power plants were located and found no major differences in terms of coverage. ${ }^{8}$

We match protest events to nuclear plants (proposed, under construction, or operating) based on geographic proximity, using the same methodology as prior research on anti-nuclear activism (Piazza and Perretti 2020; Piazza and Wang 2020). In so doing, we assume that firms whose nuclear generating facilities were located close to a protest were more likely to have been the activists' target and/or would have been associated with the protest in the mind of the regulator. Specifically, we count the number of protests that occurred each year, and in the preceding year, within 100 miles of a firm's nuclear unit(s). We use this

\footnotetext{
${ }^{8} \mathrm{We}$ conducted an extensive search using the Lexis-Nexis online database of 50 different national and regional newspapers for reports of any protest activity in the areas where nuclear power plants are situated. For each nuclear site, we bounded our search using a date range from 1960 to 1995 and used broad search terms including the nuclear site's location, state, and the term "nuclear". These searches yielded several thousand articles across all locations, which we read to identify any mention of protest activity. In the vast majority of cases (84\%), protests reported in this data set were also reported by the New York Times. In the remaining $16 \%$ of cases, we found that the protest events not covered by the New York Times were typically follow-on protests that perpetuated an initial protest that was reported by the New York Times - that is, a protest reported by the New York Times might have generated additional protests in the following days, which the newspaper did not report on. From a statistical perspective, this would mean that our models may underestimate the impact of protests. The New York Times reporting of anti-nuclear protests thus appears to provide a reliable representation of protests that occurred during our sample period.
} 
radius as most protests occurred in nearby towns or cities rather than at the actual sites of nuclear power plants, which were located in rural areas or outside urban areas. We were able to compile information on each firm's nuclear generation portfolio, including unit and plant names, location, megawatt capacity, year of announcement, and construction and operation dates (if applicable), using the Nuclear Regulatory Commission's Agency-wide Documents Access and Management System and the Power Reactor Information System database maintained by the International Atomic Energy Agency. In keeping with prior research (Piazza and Wang 2020), we match a protest to each nuclear firm within the 100-mile radius from the protest location, recognizing that a protest could have affected multiple nuclear firms in a local region. The median firm that experienced at least one protest event during our sample period had three protests overall.

Two variables capture the political environment and partisan alignment with activist causes, which we argue in Hypotheses 2 and 3 affect the sensitivity of regulatory decisions to public protests. Given the differences between the two major political parties on nuclear power policy, it is likely that Democraticcontrolled government institutions were more sympathetic towards activist organizations protesting nuclear power than were Republican-controlled institutions. Accordingly, Democratic Governor and Legislature is a binary variable equal to one if the state executive (Governor's office), House, and Senate were all controlled by the Democratic Party, and zero otherwise. Republican Governor and Legislature is constructed in an equivalent manner to measure the influence of unified Republican state government. Democratic Regulator is measured as the percentage of PUC commissioners who were members of the Democratic Party. We collected party affiliation information from individual PUC websites, the National Association of Regulatory Utility Commissioners, local newspapers reports, and directly from PUC offices. We predict that protests will have a greater negative impact on a firm's regulated rate of return when there is ideological alignment between the anti-nuclear movement and the dominant political ideology (i.e. Democratic) of government within state institutions.

To test Hypothesis 4, which argues that the spillover impact of protests is moderated by a firm's reputation with the regulator, we use the variable Performance in Prior Rate Review. To create this variable, 
we follow the methodology of the corporate reputation literature which measures reputation based on the difference between actual and predicted performance (Luo and Bhattacharya 2006; Roberts and Dowling 2002). In this context, we gauge a firm's reputation as the residual from a regression model that estimates the firm's ROR in its previous rate review where the independent variables are the same as the ones we use to test our hypotheses. ${ }^{9}$ The residuals, which are the differences between the actual ROR allowed in the prior rate review and that predicted by the regression model, are interpreted as the effect of the firm's reputation with the regulator, all else equal (Black, Carnes, and Richardson 2000). For Hypothesis 5 we measure a firm's prior accommodation of activist demands using data on cancellations of previously proposed nuclear units, a key demand of anti-nuclear activists (Kitschelt 1986; Ross and Staw 1993). ${ }^{10}$ While the number of nuclear units ordered tripled between 1970 and 1980, cancellations began to increase from the late 1970s, partly as a consequence of pressure from the anti-nuclear movement (Piazza and Perretti 2015; Piazza and Wang, 2020). The variable Nuclear Units Cancelled is a count of the number of nuclear generating units that a firm had cancelled in the previous year. We use cancellations in the prior year to measure firm accommodation of activist demands since this is within the window of the Protests variable, which is measured over the previous two years. ${ }^{11}$ The variable is constructed using cancellation data from electric utility reports to the Nuclear Regulatory Commission's Agency-wide Documents Access and Management System. We expect that a larger number of cancellations will soften the impact of protests on the regulated ROR.

\footnotetext{
${ }^{9}$ Construction of this variable decreases the number of observations for estimation of the rate of return from 1,886 rate reviews to 1,680 due to missing rate review data prior to 1970 .

${ }^{10}$ For example, the protests staged by the anti-nuclear group Abalone Alliance between 1976 and 1984 were explicitly aimed at cancellation of the nuclear power plant proposed by electric utility PG\&E at Diablo Canyon in California (see https://www.nytimes.com/1979/04/08/archives/nader-leads-protest-against-a-coast-plant-americanpublic-deceived.html). The same is true of protests that took place in New York and Long Island between 1976 and 1989 , whose target was cancellation of the Shoreham plant (see https://www.nytimes.com/1979/06/04/archives/shoreham-action-is-one-of-largest-held-worldwide-15000protest-li.html).

11 We find similar results in our empirical analysis if we instead use the number of plant cancellations since the previous rate review.
} 
In addition to the focal independent variables used to test our hypotheses, we control for state-level political and economic as well as firm-level time-varying factors that prior research has argued influences a firm's regulated rate of return. First, competition between political parties for control of state government makes elected politicians and, indirectly, regulators, more sensitive to regulatory policies that affect a large share of the electorate (Levy and Spiller 1994). We construct the variable Legislature Rivalry, which is equal to $1-\frac{\mid \text { Total Democrats-Total Republicans } \mid}{\text { Total Legislators }}$ for the state legislature where the firm is located, to capture political party competition. It has a value of zero when one party controls 100 percent of the legislature (minimal competition) and a value of one (maximum competition) when the Democrats and Republicans have an equal number of seats in the legislature. We create a similar variable, Governor Rivalry, which indicates the level of competition between candidates in the more recent gubernatorial election: the variable equals one if the winning vote margin (i.e. winner's share of the vote minus the runner-up's share of the vote) was less than five percent - indicating a close election - and zero otherwise. We anticipate that higher values of these variables, reflecting more intense political competition and greater political demand for voter-friendly regulations, will lead to lower regulated rates of return.

We include several measures of stakeholder organization in the electricity sector, which prior research has identified as affecting regulatory decisions (Bonardi et al. 2006; Fremeth, Holburn, and Spiller 2014). Environmental groups have sometimes opposed nuclear power so we incorporate League of Conservation Voter Score, a state-level annual measure of how federal legislators vote on environmental bills, which proxies for environmental pressures within a state (Delmas and Montes-Sancho 2010; Kassinis and Vafeas 2006; Kim and Lyon 2015). Consumer Advocate is a dummy variable equal to one in states and years where the government had created a publicly-funded, independent advocate to represent consumer interests in regulatory proceedings (Holburn and Vanden Bergh 2006). ${ }^{12}$ Industrial consumers tend to be relatively organized stakeholders in regulatory arenas, either individually or through industry

\footnotetext{
12 This measure varies over time since most states created advocates during the 1970s and 1980s, our sample time period. Information on state consumer advocates was gathered from the National Association of State Utility Consumer Advocates (NASUCA) and state government websites.
} 
associations, so we construct Industrial Consumers based on the annual industrial class share of electricity consumption in each state. ${ }^{13}$ We expect these variables to be associated with lower regulated rates of return.

Characteristics of regulatory institutions can also shape regulatory outcomes. More experienced PUC commissioners tend to allow lower rates of return (Fremeth et al. 2014) so we include Regulator Experience, which is the average number of years that the commissioners of the state Public Utility Commission have been in office. ${ }^{14}$ In a few states, PUC commissioners are elected by voters rather than appointed by elected politicians, and elected PUCs have been associated with more consumer-friendly regulatory rulings (Besley and Coate 2003; Bonardi et al. 2006). Hence, Elected PUC is a dummy variable that is equal to one when PUC commissioners are popularly elected and zero otherwise. ${ }^{15}$ To capture any potential remaining time-varying heterogeneity in the regulatory environment, we follow the methodology of prior research by including a dummy variable, Other Firms' Rate Reviews, which indicates whether other firms in the same state and year had initiated a rate review (Bonardi et al. 2006).

We control for the economic context within which regulatory policies are formulated. Change in Per Capita Income is the annual percentage change in personal income by state, measured using data from the Bureau of Economic Analysis, and captures the impact of state-level economic conditions on PUC regulation. We predict that higher levels of local economic growth will facilitate PUC approval of utility firm requests for higher rates of return and infrastructure investment, while dampening potential contestation from stakeholders. Similarly, Change in Interest Rate, the change in the federal interest rate on ten-year Treasury bills since the firm's last rate review, measures exogenous fluctuations in the financial environment that affect its cost of capital. Change in Fuel Cost is the percentage change in a utility firm's average fuel costs (on a per megawatt hour unit basis) since the last rate review, and is driven mainly by

\footnotetext{
13 Data on electricity consumption by consumer class was obtained from the Energy Information Administration.

14 To construct this variable we gathered the names and appointment dates of all PUC commissioners in each state from 1960 onwards from internet and state archival sources.

15 Information on PUC Commissioner selection methods was collected from The Council of State Government's Book of the States. Several states changed the method of Commissioner selection during the 1970s and 1980s.
} 
external commodity market forces. ${ }^{16}$ Increases in the cost of utilities' financial capital or fuel purchases directly reduce profits, prompting utilities to argue for rate increases. We also include the absolute level of a utility firm's fuel costs with the variable Fuel Cost since firms with higher cost structures may trigger greater levels of regulatory scrutiny and stakeholder contestation, reducing regulated rates of return. Market Share is a firm's percentage share of electricity sold within a state and reflects its relative dominance in the sector, which we expect to be positively correlated with the allowed rate of return (Bonardi et al. 2006).

Finally, we control for a firm's technological profile with several variables. Nuclear Proportion measures the firm's reliance on nuclear generation relative to other generation fuels and is calculated as the nuclear percentage share of a firm's total operating power generation plants. ${ }^{17}$ Nuclear Plants in PreConstruction Stage captures the number of nuclear plants that are in development but not yet operational. We anticipate that firms more heavily reliant on nuclear generation and those with more proposed projects will attract greater levels of stakeholder opposition and negative attention. However, once nuclear plants have been approved and are under construction, firms must raise significant amounts of financial capital. Given the scale and complexity of nuclear plant construction and operation, access to capital markets requires nuclear power generators to earn a higher rate of return (World Nuclear Association 2020; Thomas 2010). We thus include the number of Nuclear Plants in Construction Stage, which we expect to be associated with a higher regulated rate of return. Overall, almost half of the firms (94 of 206) were involved in nuclear generation during the study window.

Table 1 provides descriptive statistics for all the variables in our analysis, as well as the correlation matrix. The mean of the Variance Inflation Factors (VIF) is 1.41 with no single VIF above 1.8 across our variables, which is below the conservative threshold of 2.5 (Allison 1999), reducing concerns about multicollinearity.

\footnotetext{
${ }^{16}$ We use state-level average utility fuel costs to construct this variable and also Fuel Cost since utility-level fuel cost data is not available for the 1970s period. Utility fuel cost data was obtained from the Energy Information Administration.

17 Data on each firm's generation profile, including the type of technology, were collected for each year from the Energy Information Administration.
} 
[Insert Table 1 about here]

Method. In order to empirically identify the spillover impact of public protest events on firms' regulatory outcomes, we leverage the panel structure of our data, which includes variation in the incidence of protests both within-firms over time and also between firms in each year. During the 26-year period of study, 73 out of 206 firms in the industry (35\%) experienced protests as defined above. Given the timeseries and cross-sectional variation in our data, we employ a fixed effects regression model (Angrist and Pischke 2009), which enables us to control for unobserved fixed firm-level characteristics that could be correlated with the level of activism, the omission of which would bias coefficient estimates of the impact of protests. For instance, individual firms could experience higher or lower levels of protest activity due to the demographic composition of their consumer base (e.g., urban versus rural) - which generally changes only very slowly - in their geographic monopoly territory. Similarly, year fixed effects control for temporal variation in nation-wide activism patterns over the time period. ${ }^{18}$ Robust standard errors are clustered by firm in all models to address potential autocorrelation in the panel.

We account for two potential sources of endogeneity in our econometric model that could bias coefficient estimates. First, regulatory agency decisions on the regulated ROR, our dependent variable, do not occur randomly but only when rate reviews are requested by firms, which creates a possible sample selection problem: firms may avoid or postpone rate reviews if they anticipate an unfavorable outcome, for instance following a public protest against nuclear power. Coefficient estimates of variables included in a linear regression model of the regulated rate of return would be biased if these variables also influence a firm's decision to request a rate review. Consistent with other studies of regulatory outcomes in the electric utility sector (see Bonardi et al. 2006; Fremeth et al. 2014; Joskow 1974; Roberts et al. 1978), we use a Heckman two-stage model to correct for selection effects in the linear regression (Heckman 1979). On

\footnotetext{
18 The inclusion of this rich set of high-dimensional fixed effects is an advance over Bonardi et al's (2006) study of regulatory outcomes in the electricity sector, which included state-level but not firm-level fixed effects.
} 
average, firms requested a rate review approximately every three years, leading to about eight rate reviews (and ROR decisions) per firm during our 26-year time period.

The Heckman selection model uses a probit model to estimate the likelihood of a firm initiating a rate review in a year, and then corrects coefficient estimates in the linear regression using the inverse Mills ratio. Variables included in the ROR regression model are used in the probit model since these are expected to influence the firm's decision to request a rate review. In order to satisfy the exclusion restriction requirement of the Heckman model (Certo et al. 2016), we also include a variable that is a predictor of selection (i.e. rate review initiation) but not a predictor of the outcome variable in the regression model (ROR). We thus include the variable Change in Electricity Consumption, defined as the percentage change in electricity consumed in a state over the preceding two years. The rationale for this instrument is that increased electricity consumption is driven by broader economic growth - an exogenous factor - that causes electric utilities to invest in new infrastructure in order to meet growing demand (Ford 1999; Fremeth and Holburn 2012; Joskow 2006). The need for new investment raises the propensity for firms to initiate a rate review as regulatory approval of such investment is the only way for firms to recover the cost in the allowed cost base (Hyman 2000). However, the level of investment does not affect the PUC's assessment of the firm's regulated ROR, which is a separate and distinct PUC decision during a rate review (see Appendix A) - so this variable is logically not included in the linear regression model. ${ }^{19} \mathrm{We}$ follow Certo et al.'s (2016) recommendation of reporting the full first-stage probit model results, the pseudo- $\mathrm{R}^{2}(0.190)$ of the model, and the statistical significance of the inverse Mills ratio $(p<0.01)$.

A second endogeneity concern arises around non-random occurrence of protests (McDonnell and King 2013; McDonnell and Werner 2016), for instance due to unobserved factors such as local community activism, which can vary over time, affecting the degree of protest activity against a firm and potentially also regulatory decisions. To address this issue, we adopt an instrumental variable approach where we

${ }^{19}$ As a robustness check we also tested an alternative exclusion restriction variable (Wolfolds and Siegel 2019), the percentage change in electricity consumption over the preceding two years in neighboring states to the focal utility. Results using this alternative variable are consistent with those presented in the tables. 
instrument for the number of anti-nuclear protests using the number of protests on all other issues (e.g. civil rights, gender equality, animal welfare, environment) that occurred in the same vicinity (Piazza and Wang 2020). We argue that the incidence of non-nuclear protests should reflect the propensity of a local population to protest - an otherwise omitted variable - which should be correlated with the incidence of anti-nuclear protests (see Piazza and Perretti 2020) but importantly it should not be correlated with our outcome variable, an electric utility's regulated ROR. For example, protests about civil rights or animal welfare are not expected to impact PUC decision-making on a utility's regulated rate of return. Non-nuclear protest data also came from Stanford's Dynamics of Collective Action Project database, which includes 15,467 non-nuclear protest events during our sample period. The instrument was constructed in a similar way to Protests using the number of non-nuclear protests that occurred within a 100-mile radius of a firm's nuclear unit(s) in each year and in the preceding year. In the construction of the instrument, non-nuclear protests explained 28\% of the variation in Protests with an F-statistic of 142, which is well above the rule of thumb when testing for weak instruments (Stock and Yogo 2002). ${ }^{20}$ We also calculated Altonji, Elder, and Taber's (2005) selection-on-unobservables to selection-on-observables ratio to examine the potential explanatory power of unobserved factors on the non-instrumented estimates. Unobserved factors would need to explain 2.5 to 3.6 times more variation in our dependent variable than the included variables in order to fully explain our effect size, which is greater than the 1.0 times threshold for a robust estimate, further reducing, albeit not eliminating, concerns about endogeneity biases.

\section{Results}

In Table 2 we present the results of Heckman models that estimate the statistical relationship between public protests (using the instrumental variable) and electric utility firms' regulated financial rates of return. Model 1 shows the results of the rate review initiation probit model, finding that recent antinuclear activist protests have a negative association with the likelihood of a firm initiating a rate review.

\footnotetext{
${ }^{20}$ In addition to this instrument, we examined firm size and a lagged measure of Protests as alternative instruments. Results using these instruments were similar to those using the non-nuclear protest instrument.
} 
The estimated coefficient on Protests is negative (as expected) and statistically significant at the five percent confidence level. Economic factors also influence the incidence of rate reviews: increases in interest rates and fuel costs since a firm's previous rate review increase the likelihood of a new rate review. Similarly, the positive and statistically significant coefficient on Nuclear Plants in Construction Stage indicates that once new plants have received regulatory approval and are under construction, firms seek approval through rate reviews for rate increases to recover new capital costs. Firms with higher average fuel costs are generally less likely to initiate rate reviews, consistent with anticipated greater levels of regulatory scrutiny and stakeholder opposition towards firms that are perceived to be less efficient. Firms are also less likely to initiate a review when political party competition is higher in the legislature. On the other hand, firms are more likely to initiate rate reviews when other firms have done so within the same state and year. These results are consistent with expectations about factors that influence a firm's strategic decision to request regulatory review, and the statistically significant coefficient on the Inverse Mills Ratio (in Model 2) demonstrates the importance of controlling for selection effects in the rate of return regression.

Models 2a to 2e present the results of the regulated Rate of Return regression models, controlling for selection, rotating in the primary independent variables used to test the hypotheses. Model 2a includes all the variables except the interaction terms used for testing Hypotheses 2-5. The coefficient on Protests is negative and statistically significant at the five percent confidence level, and it is also economically meaningful: a one standard deviation increase from the mean in the number of protests is associated with a four-and-a-half basis point decrease in the regulated rate of return. This is equivalent to seven percent of the average difference between the firm's requested rate of return and the PUC's determination of the regulated rate of return during rate reviews. ${ }^{21}$ This provides support for our first hypothesis: that protests targeting firms' contentious activities spill over into non-targeted aspects of firm regulation.

${ }^{21}$ At the commencement of a rate review, electric utility firms submit a requested level of the regulated rate of return for the PUC to consider. The average ROR requested by firms in our sample is $10.54 \%$, while the ROR ultimately allowed by the PUC is $9.89 \%$ on average, a difference of 65 basis points. 
Models $2 \mathrm{~b}$-e in Table 2 include interaction terms for testing the conditional hypotheses. Interpreting the statistical significance of variables included in interaction terms is not straightforward since statistical significance varies depending on the values of the underlying variables - meaning that the estimated statistical significance of a single variable coefficient is not necessarily an indicator of overall statistical significance (Brambor, Clark, and Golder 2006). We therefore estimate the statistical significance of Protests $x$ Democratic Regulator, Protests $x$ Democratic Governor and Legislature, Protests $x$ Performance in Prior Rate Review and Protests $x$ Nuclear Units Cancelled at different values of the focal variables. To facilitate interpretation of the models with interaction terms, we calculate in Table 3 the estimated marginal effects of an additional protest on the regulated rate of return.

\section{[Insert Table 3 about here]}

In Table 3a we assess the interaction between Protests and Democratic Governor and Legislature, which tests Hypothesis 2, and present the marginal effect of an additional protest. As predicted, the marginal impact of anti-nuclear protests on the regulated rate of return is greater when the state government is controlled by Democrats. When the value of Democratic Governor and Legislature equals one, the marginal effect of Protests increases by more than nine times compared to environments where the government is politically divided. Increasing the number of protests by one standard deviation from the mean value during a period of Democratic control is associated with a reduction of eight basis points from the baseline average. We thus find strong statistical support for Hypothesis 2: the negative spillover impact of protests on a firm's ROR is exacerbated when there is ideological alignment between executive and legislative branches of government and also between activists in opposition to contentious activities of the firm - ratcheting up pressure on administrative agencies to scrutinize utilities and to tighten regulatory policies. $^{22}$

$22 \mathrm{We}$ also estimated the same model but interacted Protests with an indicator variable for Republican control of the Legislature and Governor's office in place of Democratic control. The estimated impact of Protests conditional on Republican control was not statistically significant. 
Table $3 \mathrm{~b}$ presents evidence in support of Hypothesis 3, that anti-nuclear protests had a substantially greater negative impact on a firm's regulated rate of return when the regulatory agency was dominated by commissioners affiliated with the Democratic Party, which, at the national level, was seen as less supportive of nuclear power than the Republican Party. Coefficient estimates are negative and statistically significant for values of Democratic Regulator greater than 50 percent, though not for values less than 40 percent that is, when agencies were controlled by Republican commissioners. The magnitude of the marginal estimate for Protests increases with Democratic Regulator: if the regulatory agency was completely controlled by Democrats (Democratic Regulator $=100$ percent), the marginal impact of protests is more than three times the amount than if the agency was evenly divided between Democrats and Republicans. In this situation, increasing Protests by one standard deviation from its mean value is associated with a reduction in the firm's regulated rate of return of 12 basis points ( 0.12 percentage points). This represents about $18 \%$ of the difference between the ROR requested by a firm and that allowed by the PUC. We thus find strong statistical support for Hypothesis 3.

Table 3c shows the results of Model 2d, which estimates the impact of anti-nuclear protests depending on a firm's reputational standing with the regulator, thereby testing Hypothesis 4. Estimates of the marginal impact of a protest at different values of Performance in Prior Rate Review indicate that the magnitude of a protest's negative effect diminishes for firms with better prior rate review outcomes (with higher prior performance residuals). Coefficient estimates are statistically significant for most of the range of Performance in Prior Rate Review. For firms a standard deviation below the mean of Performance in Prior Rate Review, a standard deviation increase in the number of protests is associated with an eight basis point decrease in the allowed ROR. By contrast, for firms a standard deviation above the mean value those with more favorable reputations - the marginal impact of protests is practically zero. This provides 
strong support for Hypothesis 4, that a firm's standing with the regulator positively moderates the spillover effect of protests. $^{23}$

Estimates of the marginal impact of protests conditional on the firm's prior cancellation of planned nuclear power generation units, which tests Hypothesis 5, are presented in Table 3d. Coefficient estimates of Protest are statistically significant at the five percent or one percent level of confidence at all values of Nuclear Units Cancelled, and the magnitude of the negative impact declines as the number of cancelled nuclear units increases. For a firm that had not cancelled any nuclear units, a standard deviation increase in Protest is associated with a five basis point penalty on its regulated ROR. The marginal impact of protests on the ROR shrinks to almost zero for a firm that had previously cancelled two nuclear units, and becomes positive when three or more units had been cancelled. This pattern of results suggests that regulators are less likely to interpret and react negatively to protests when targeted firms have a stronger track record of responding to protestors' concerns and demands. We thus find strong support for Hypothesis 5.

In addition to our estimates for the focal independent variables, coefficient estimates for a number of control variables are statistically significant and signed as expected. States with greater political party rivalry in the legislature are associated with firms receiving lower regulated RORs, consistent with findings of prior research (Fremeth et al. 2014). A one standard deviation increase in the value of Legislature Rivalry is estimated to reduce a firm's ROR by thirteen basis points on average, all else equal. Stronger support for environmental policies in a state, as indicated by higher League of Conservation Voters scores, is associated statistically with less favorable rate review outcomes as previous research has also found (Bonardi et al. 2006). We do not find statistically significant effects of Consumer Advocate, Industrial Consumers and

${ }^{23}$ As an alternative approach to testing Hypothesis 4, we re-estimated the main model (excluding the Performance in Prior Rate Review residual measure of firm reputation) with the data split into two - one subsample included observations where the firm's allowed ROR in the last review was below the nationwide median for that year, the other subsample included observations where the firm's prior allowed ROR was above the national median. By estimating the model for each sub-sample we estimated the impact of protests separately for firms with an assumed strong reputation (prior ROR above the median) and for firms with an assumed weak reputation (prior ROR below the median). Comparing the estimated negative coefficient for Protests in each sample, we found that it was larger for the sample of firms with prior RORs below the median, consistent with our prediction in Hypothesis 4 . The results are presented in Table B.3 of Appendix B. 
Elected PUC, which is likely to be attributable to the inclusion of high-density fixed effects in the models and minimal variation over time in these variables. Firms that are relatively more reliant on nuclear power within their operating generation portfolio tend to receive higher regulated RORs, as has been previously documented in the regulatory finance literature, due to the scale and technological complexity of nuclear facilities (World Nuclear Association 2020; Thomas 2010): a one standard deviation increase in the value of Nuclear Proportion of Plants is associated with a sixteen basis point increase in a firm's ROR. Similarly, when planned nuclear plants enter the construction stage, firms tend to receive a higher ROR (reflecting the significant financial capital requirements), as indicated by the positive and statistically significant coefficient on Nuclear Plants in Construction Stage. However, when proposed nuclear plants are in the early stages of development and are awaiting approval, RORs tend to be lower, which is consistent with elevated levels of stakeholder opposition during this period: the coefficient for Nuclear Plants in PreConstruction Stage is negative and statistically significant, and is estimated to reduce a firm's ROR on average by eighteen basis points for each additional plant.

Robustness. We conducted a variety of sensitivity tests, including alternative variable definitions, model specifications and empirical methods, to evaluate the robustness of our statistical findings (Appendix B reports the results). First, as an alternative to the count of protests, our primary independent variable, we used the sum of protest days to reflect differing event durations; most protests lasted for one day, but a nonnegligible minority (eight percent) lasted for longer, and one percent endured more than a week. We also used a smaller (50-mile) geographic radius to match the location of anti-nuclear protests to nuclear plants instead of a 100-mile radius. We also counted protests that occurred only in the year of a rate review and separately in just the preceding year as alternative measures of our focal independent variable. In each case, the pattern of results was very similar to the results from our main model (see Tables B.1 and B.2 in Appendix B).

To further examine the influence of political ideology within a state, we included Poole and Rosenthal's 'DW-Nominate' score for a state's elected federal legislators, which is commonly used in the political science literature to measure politicians' positions on a continuous conservative-liberal ideology 
spectrum (Poole and Rosenthal 1985). Adding the $D W$-Nominate variable to our model did not materially change the estimated results for the Protest variable or the political party control variable, Democratic Governor and Legislature, which tests Hypothesis 2. A potential concern in interpreting the results for the Protests variable is that it may reflect the impact of anti-nuclear groups through participation in formal regulatory rate review hearings, during which firms and stakeholders present information and arguments to PUC staff and commissioners, rather than the impact of coincident public protests per se. To test this alternative mechanism, we collected data on the identities of all stakeholders who participated in rate reviews from 1980 to 1995, and found that anti-nuclear organizations very rarely participated, featuring in only $61(5 \%)$ of the 1,186 rate reviews. ${ }^{24}$ This substantially reduces concern about omitted variable bias, but as a further check we estimated our models for the period 1980 to 1995 including a binary indicator variable for whether an anti-nuclear group participated in a rate review. The coefficient estimate on this variable was not statistically significant and results for the main hypothesis-testing variables were virtually unchanged, improving our confidence in the model's identification of a causal impact of protests. Table B.4 presents these results.

To address any remaining concern about endogeneity bias arising from differences between protested and non-protested firms that are not captured by the independent variables and firm fixed effects, as well as by the instrumented protest variable, we estimated the impact of protests using a matched sample of firms based on the propensity to be targeted by a protest in a given year (see Table B.5). We used the coarsened exact matching method to calculate propensity scores using Nuclear Proportion of Plants, Market Share, League of Conservation Voters Score, and Democratic Governor and Legislature, reflecting

\footnotetext{
24 We collected data on the identities of all stakeholders who participated in rate reviews from primary rate review documents, which we obtained from PUC websites and from information requests submitted to PUC offices, utilities and state libraries. We were able to obtain complete intervenor data only for rate reviews from 1980 onwards. The most frequent types of stakeholders participating in rate reviews were those representing industrial, commercial and residential consumers. The infrequent participation of anti-nuclear groups is perhaps not surprising since their comparative advantage is typically in mobilizing public support through protests and events, and in attracting media attention.
} 
both firm and state-level factors that predict the likelihood of observing a protest. ${ }^{25}$ Each firm that experienced a protest was accordingly matched with a comparable firm that was not protested. While the matching method reduces the number of observations as compared to the Heckman model, which utilizes the full panel dataset, the estimated impact of protests was similar. We also estimated this matching model using the non-instrumented measure for Protests and found consistent results.

A significant number of nuclear plants are located in proximity to population centres in the northeast region of the U.S., where a large fraction of protests also occurred. To explore possible geographic regional variation in the impact of protests, we re-estimated the models on a sample that excluded firms located in six states in the region, as defined by the U.S. Bureau of Economic Analysis regional classification scheme (Delaware, District of Columbia, Maryland, New York, New Jersey, and Pennsylvania). Excluding these firms reduced the sample size by a fifth, but the results remained robust statistically and economically, suggesting that the estimated effect of protests on regulated rates of return is not driven by this particular region. Similarly, we re-estimated our models excluding the top 5\% of firms with the greatest number of protests during the sample period, and separately dropping protests from the peak-protest years 1979 and 1980. The estimated effects remain similar to the full sample estimate in each case, suggesting that it is not driven by the inclusion of a small subset of observations. These results are presented in Table B.6 of Appendix B.

We also examined whether protests that occurred within the vicinity of a single firm's nuclear plant had a differential impact on regulatory outcomes compared to protests that took place near several firms' plants. To conduct this test, we decomposed the Protests variable into two components, the count of Protests (Single Plant) and the count of Protests (Multi-Plant), each within a 100-mile radius of a firm's nuclear plant. Coefficient estimates on both these variables were negative and individually statistically significant, but not statistically different in magnitude when compared using an F-Test of coefficient

\footnotetext{
25 In addition, we estimated matching models where we restricted matches to only firms within the same state. While the limited sample size of the matching model reduced the levels of statistical significance, the estimated results for Protests were qualitatively consistent with the main models.
} 
equality. To further test this relationship, we limited the radius to 50 miles and found a similar pattern of results (see Table B.7).

We evaluated whether the proximity of protests to state regulator offices as well as to a firm's nuclear plants could affect the extent of regulatory responses. We again separated the Protests variable into two parts, the count of protests within 100 miles of a firm's nuclear plant and also within 100 miles of the city of the state capital (where most PUC offices are located), and the count of protests within 100 miles of a firm's nuclear plant but more than 100 miles from the state capital. The coefficient on the former protest variable was negative and statistically significant while the coefficient on the latter variable was not statistically significant, indicating that protests occurring closer to PUC offices had more pronounced negative spillovers on the firm's ROR. Relatedly, we explored whether protests that occurred within the same state as a firm had a differential impact on the firm's regulatory outcomes. Along with the central measure of protests, we added a new variable to the main model, the count of protests within the same state as the firm's plant but further than 100 miles from the plant. The coefficient estimate of the central protests variable remained statistically significant but the coefficient estimate for the new variable was not statistically significant (see Table B.7), suggesting that the geographic proximity of protests was more important for regulatory outcomes than whether protests occurred in the same state. Together, these findings indicate that the geographic location of protests - proximity to firms and to key stakeholders such as industry regulators - is an important factor in understanding the extent of protest spillovers in non-targeted domains.

While year fixed effects capture the nation-wide impact of idiosyncratic factors and events such as the 1979 Three Mile Island accident, we also considered other measures of temporal variation, including a linear time trend variable and a Pre/Post-1979 era binary variable. In each of these alternative models, the coefficient estimates on Protests and the key moderating variables remained consistent with the main models. We also interacted Protests with the Pre/Post-1979 variable and found no statistically significant effect (see Table B.8), suggesting that the spillover impact of protests on firms' regulatory outcomes did not measurably change after the Three Mile Island accident. 


\section{Discussion and Conclusion}

In this paper we examine how social activism - in the form of protests against contentious firm practices - can spill over into the regulatory domain, extending beyond activists' articulated goals to affect firms' regulatory outcomes in areas that are not directly targeted. We argue that firms are likely to experience broader regulatory repercussions after activist protests because public contention invites greater scrutiny of firm behavior and practices by industry regulators. Protests can also cause regulators to evaluate targeted firms more negatively and to signal their commitment to protecting the public interest, especially for firms with less favorable pre-existing reputations or stakeholder relations. Building on the political mediation model of social movement outcomes, we further contend that the political context within which regulatory agencies operate shapes the extent of protest spillovers: when political institutions are aligned with activist goals, and when regulators are ideologically sympathetic too, protests have a more pronounced negative impact on firms' regulatory outcomes in non-targeted domains.

We find robust support for our predictions in an empirical analysis of the impact of activist protests against electric utilities' nuclear power generation projects on utilities' regulated financial rates of return, a context that has some unique statistical advantages. Our dataset incorporates all firms in a single industry, including protested and non-protested firms, and it covers a 26-year period, during which multiple protest events occurred. The cross-sectional and time-series variation in the data assists in statistically identifying a causal impact of anti-nuclear protests on the regulatory outcomes of firms involved in nuclear power generation after controlling for observed and unobserved fixed firm-level characteristics and after modeling the potential endogeneity of protests themselves. A second advantage of the industry setting is that the dependent variable, the regulated financial rate of return, is a firm-specific regulatory outcome measure. It is also a widely salient aspect of regulatory policy over which regulators have discretion to tilt towards favoring firms or consumers, yet which is not the focus of the activists' articulated goals, making it an appropriate dimension for testing for the presence of protest spillover effects on regulation. Our statistical investigation finds that anti-nuclear protests, which were primarily focused on halting construction and development of firms' nuclear facilities, were associated with firms subsequently achieving lower regulated 
financial rates of return in rulings by independent regulators, consistent with an indirect or spillover impact. The estimated magnitude of the effect was greater for firms with less favorable reputations with regulators and for those that had been less accommodating of activist demands around nuclear development, and in institutional environments where the dominant political ideologies of government and regulators were aligned with anti-nuclear activists.

Our insights contribute to emergent research on the spillover effects of activism which, relative to articulated or intended activist demands, may be just as or more consequential for firm performance (e.g. Briscoe, Gupta, and Anner 2015; Ferguson, Dudley, and Soule 2018; King and Soule 2007). Consumer boycott campaigns, for example, often do not manage to meaningfully change consumer purchase decisions, but a few studies have indicated that other stakeholders, such as elected politicians (McDonnell and Werner 2016) and investors (King and Soule 2007) may react, undertaking measures that distance themselves from the targeted firm. Our analysis here extends the spillover argument into the regulatory domain and to industry regulators who, given their public interest mandate and accountability to political institutions, are likely to be sensitive to the cues associated with protests against contentious activities. Indeed, the increasing politicization of regulatory agencies and the weakening of independence that has been observed in recent years in countries such as the United States suggests that regulators may become more responsive to social activism. For firms that are subject to activist campaigns, even if a firm 'wins' the immediate contested issue there could still be subsequent adverse repercussions as other stakeholders, including industry regulators, respond to activists' claims. Since regulations, once implemented, are not easily reversed or modified, the negative regulatory consequences of protests may impact firms for an extended time period.

While our analysis examines variation in spillover impacts conditional on firm-level and political contextual factors, in exploratory analyses we also considered the importance of activist organizational characteristics, which could present a boundary condition to our theoretical model. Activist organizations vary in their resources and in their abilities to mobilize supportive constituents and to publicly communicate their messages - factors which increase pressure on politicians and regulators. Hence, protests by 
established activist organizations, such as Sierra Club or Friends of the Earth, are likely to send stronger signals to government policymakers, and to have greater spillover effects, than protests arranged by local or lesser known activist groups. To explore this prediction, we re-estimated our model with the Protests variable split into two types - protests led by known organizations and protests where no named activist organizations were recorded as participating. The results indicated that protests by known organizations had a greater negative impact on firms' regulated financial rates of return than did protests led by unnamed groups, consistent with our expectation (see Appendix B Table B.9). Understanding how activist resources and capabilities affect the extent of protest spillovers is a topic that warrants deeper consideration in future research.

Our findings also extend scholarly understanding of the varied impacts of 'private politics' on firm performance and strategy, which existing research has largely explored in the context of market-based outcomes. By publicly damaging firms' reputations, scholars have argued that social activism prompts stakeholders such as suppliers, investors, customers and employees to reconsider their economic relationships with targeted firms, motivated by their own reputational concerns or moral principles (King and Soule 2007; Vasi and King 2012). Here we argue that industry regulators, who are charged with regulating in the public interest, are also sensitive to social activism directed towards firms within their jurisdiction. Protests and claims of harmful firm behavior can lead regulators to impose financial penalties or tighten the stringency of regulations, particularly for firms where the regulator may already have doubted the probity of its actions or management.

By focusing on the relationship between activism and regulation, our paper helps to integrate studies of 'private politics' and 'public politics', two streams of nonmarket strategy research that have largely developed separately with little cross-fertilization. Public politics strategy research has focused on lobbying, election campaign contributions, and stakeholder mobilization - which firms use in pursuit of more supportive public policies - while the more recent private politics strategy literature has explored strategic interactions between firms and social activists, studying how firms manage the impact of activist campaigns that aim to disrupt their business operations. Our study identifies important interdependencies 
between these two research streams, raising new questions that could be addressed by future research that integrates these literatures. For instance, to what extent can firms rely on lobbying or stakeholder mobilization as defensive tactics to mitigate the negative impact of activist campaigns on regulatory policies? Some recent studies have found that firms attempt to bolster their public reputations through making pro-social claims following boycott campaigns (McDonnell and King 2013), which may affect regulators' and politicians' perceptions of the firm as well as those of consumers. Research could also examine the conditions when activist protests are more harmful to firms through their impact on public policies or else through their effect on primary stakeholder relationships (e.g. consumers, suppliers or investors).

There are naturally a variety of limitations to our analysis, which should lead to some caution in drawing general conclusions. First, our empirical investigation is centered on firms in a single industry, electric utilities, which is arguably more susceptible to public and political pressures than other industries. While most industries are subject to some degree of government regulation, virtually all citizen voters are also consumers of electricity services, which are deemed essential for modern day living - making issues around electricity sector development and pricing particularly salient for both consumers and politicians. As such, social activism and public protests may be more impactful on firms' regulatory outcomes in this industry context than in others that assume a lower priority on political agendas. A second limitation is that we study protest spillovers on one dimension of regulatory policy, the financial rate of return, which we contend is important for a range of competing stakeholders and which is also subject to regulatory discretion. Other aspects of regulation may be less likely to be affected indirectly by protests; future work could explore the types of regulatory domains that are more or less sensitive to spillovers and develop more nuanced predictions. Finally, while our focus is on explaining firms' regulatory outcomes, a limitation of the study is that we are unable to incorporate direct measures of nonmarket strategy or tactics (such as lobbying) that firms may use to improve their nonmarket environment. However, to the extent that such actions partially offset the (negative) spillover effect of organized protests on regulatory outcomes, the estimated coefficients in the empirical model will understate the magnitude of the true impact. 
In conclusion, our study develops new insights for research on the effects of social activism on firm performance and strategy, highlighting the spillover consequences of public protest campaigns for regulatory outcomes that are not activists' direct target. While considerable research has documented the direct effects of social activism, this is one of a few studies to explicitly explore why indirect impacts in the regulatory environment may also be expected. We hope that future work will address the limitations of our analysis and explore the mechanisms we propose that cause regulators to respond directly and indirectly to protest events. 


\section{References}

Allison, Paul D. 1999. Multiple Regression: A Primer. Thousand Oaks, CA: Pine Forge Press.

Altonji, Joseph G., Todd E. Elder, and Christopher R. Taber. 2005. "Selection on Observed and Unobserved Variables: Assessing the Effectiveness of Catholic Schools." Journal of Political Economy 113(1):151-84.

Amenta, Edwin. 2006. When Movements Matter: The Townsend Plan and the Rise of Social Security. Princeton, NJ: Princeton University Press.

Amenta, Edwin, Neal Caren, Elizabeth Chiarello, and Yang Su. 2010. "The Political Consequences of Social Movements." Annual Review of Sociology 36(1):287-307.

Amenta, Edwin, Bruce G. Carruthers, and Yvonne Zylan. 1992. "A Hero for the Aged? The Townsend Movement, the Political Mediation Model, and U.S. Old Age Policy, 1934-1950." American Journal of Sociology 98(2):308-39.

Andrews, Kenneth T. 2001. "Social Movements and Policy Implementation: The Mississippi Civil Rights Movement and the War on Poverty , 1965 to 1971." American Sociological Review 66(1):71-95.

Angrist, Joshua D. and Jörn-Steffen Pischke. 2009. Mostly Harmless Econometrics: An Empiricist's Companion. Princeton, NJ: Princeton University Press.

Anon. 2020. "Economics of Nuclear Power." Retrieved April 10, 2020 (https://www.worldnuclear.org/information-library/economic-aspects/economics-of-nuclear-power.aspx).

Aranda, Ana M. and Tal Simons. 2018. "On Two Sides of the Smoke Screen: How Activist Organizations and Corporations Use Protests, Campaign Contributions, and Lobbyists to Influence Institutional Change.” Pp. 261-315 in Research in the Sociology of Organizations. Vol. 56. Emerald Group Publishing Ltd.

Artiach, Tracy, Helen Irvine, Janet Mack, and Christine Ryan. 2016. "The Legitimising Processes of a New Regulator: The Case of the Australian Charities and Not-for-Profits Commission." Accounting, Auditing \& Accountability Journal 29(5):802-27.

de Bakker, Frank G. a. and Frank den Hond. 2007. "Ideologically Motivated Activism: How Activist Groups Influence Corporate Social Change Activities." Academy of Management Review 32(3):90124.

Baron, David P., Margaret Neale, and Hayagreeva Rao. 2016. "Extending Nonmarket Strategy: Political Economy and the Radical Flank Effect in Private Politics." Strategy Science 1(2):105-26.

Bartley, Tim and Curtis Child. 2014. "Shaming the Corporation: The Social Production of Targets and the Anti-Sweatshop Movement.” American Sociological Review 79(4):653-79.

Besley, Timothy and Stephen Coate. 2003. "Centralized versus Decentralized Provision of Local Public Goods: A Political Economy Approach.” Journal of Public Economics 87(12):2611-37.

Bever, Lindsey. 2018. “\#DeleteFacebook: Apple Co-Founder Steve Wozniak Deletes Facebook over Privacy Concerns." The Washington Post, April 9.

Black, E. L., T. A. Carnes, and V. J. Richardson. 2000. "The Market Valuation of Corporate Reputation." Corporate Reputation Review 3(1):31-42.

Bonardi, Jean-Philippe, Guy L. F. Holburn, and Richard G. Vanden Bergh. 2006. "Nonmarket Strategy Performance: Evidence From U.S. Electric Utilities.” Academy of Management Journal 49(6):120928.

Brambor, Thomas, William Roberts Clark, and Matt Golder. 2006. "Understanding Interaction Models: Improving Empirical Analyses." Political Analysis 14(1):63-82.

Briscoe, Forrest and Abhinav Gupta. 2016. "Social Activism in and Around Organizations." Academy of Management Annals 10(1):671-727.

Briscoe, Forrest, Abhinav Gupta, and Mark S. Anner. 2015. "Social Activism and Practice Diffusion: How Activist Tactics Affect Non-Targeted Organizations." Administrative Science Quarterly 60(2):300-332.

Carpenter, Daniel P. 2001. The Forging of Bureaucratic Autonomy: Reputations, Networks, and Policy Innovation in Executive Agencies, 1862-1928. Princeton, NJ: Princeton University Press. 
Certo, S. Trevis, John R. Busenbark, Hyun-Soo Woo, and Matthew Semadeni. 2016. "Sample Selection Bias and Heckman Models in Strategic Management Research.” Strategic Management Journal 37(13):2639-57.

Daubert, Victoria L. and Sue Ellen Moran. 1985. Origins, Goals and Tactics of the U.S. Anti-Nuclear Protest Movement. RAND Corporation.

Delmas, Magali A. and Maria J. Montes-Sancho. 2010. "Voluntary Agreements to Improve Environmental Quality: Symbolic and Substantive Cooperation." Strategic Management Journal 31(6):575-601.

Diermeier, Daniel. 2011. Reputation Rules: Strategies for Building Your Company's Most Valuable Asset. New York, NY: McGraw-Hill.

Durand, Rodolphe and Jean-Philippe Vergne. 2015. "Asset Divestment as a Response to Media Attacks in Stigmatized Industries.” Strategic Management Journal 36(8):1205-23.

Eesley, Charles E., Katherine A. Decelles, and Michael Lenox. 2016. "Through the Mud or in the Boardroom: Examining Activist Types and Their Strategies in Targeting Firms for Social Change." Strategic Management Journal 37(12):2425-40.

Eesley, Charles and Michael J. Lenox. 2006. "Firm Responses to Secondary Stakeholder Action." Strategic Management Journal 27(8):765-81.

Ewans, Lewis and Steven Garber. 1988. "Public-Utility Regulators Are Only Human: A Positive Theory of Rational Constraints." American Economic Review 78(3):444-62.

Fassiotto, Magali A. and Sarah A. Soule. 2017. "Loud and Clear: The Effect of Protest Signals on Congressional Attention." Mobilization 22(1):17-38.

Feinberg, Matthew, Robb Willer, and Chloe Kovacheff. 2020. "The Activist's Dilemma: Extreme Protest Actions Reduce Popular Support for Social Movements." Journal of Personality and Social Psychology 119(5):1086-1111.

Ferejohn, John A. and Charles Shipan. 1990. "Congressional Influence on Bureaucracy.” Journal of Law, Economics, \& Organization 6(April 1990):1-20.

Ferguson, John-Paul, Thomas Dudley, and Sarah A. Soule. 2018. "Osmotic Mobilization and Union Support during the Long Protest Wave, 1960-1995.” Administrative Science Quarterly 63(2):44177.

De Figueiredo, Rui J. P. and Geoff Edwards. 2007. "Does Private Money Buy Public Policy? Campaign Contributions and Regulatory Outcomes in Telecommunications." Journal of Economics and Management Strategy 16(3):547-76.

Ford, Andrew. 1999. "Cycles in Competitive Electricity Markets: A Simulation Study of the Western United States.” Energy Policy 27(11):637-58.

Fremeth, Adam, Guy L. F. Holburn, and Richard G. Vanden Bergh. 2016. "Corporate Political Strategy in Contested Regulatory Environments.” Strategy Science 1(4):272-284.

Fremeth, Adam R. and Guy L. F. Holburn. 2009. "Information Asymmetries and Regulatory RateMaking." in Regulation, Deregulation, Reregulation: Institutional Perspectives, edited by C. Menard and M. Ghertman. Cheltenham, UK: Edward Elgar.

Fremeth, Adam R. and Guy L. F. Holburn. 2012. "Information Asymmetries and Regulatory Decision Costs: An Analysis of U.S. Electric Utility Rate Changes 1980-2000.” Journal of Law, Economics, and Organization 28(1):127-62.

Fremeth, Adam R., Guy L. F. Holburn, and Pablo T. Spiller. 2014. "The Impact of Consumer Advocates on Regulatory Policy in the Electric Utility Sector.” Public Choice 161(1-2):157-81.

Fuller, John G. 1975. We Almost Lost Detroit. New York, NY: Reader's Digest.

Gamson, William A. 1975. The Strategy of Social Protest. Homewood, IL: Dorsey.

Gamson, William A. and Andre Modigliani. 1989. "Media Discourse and Public Opinion on Nuclear Power: A Constructionist Approach.” American Journal of Sociology 95(1):1-37.

Giugni, Marco G. 1998. "Was It Worth The Effort? The Outcomes and Consequences of Social Movements." Annual Review of Sociology 24(1):371-93.

Giugni, Marco G. 2004. Social Protest and Policy Change: Ecology, Antinuclear, and Peace Movements 
in Comparative Perspective. Lanham, MD: Rowman and Littlefield.

Goodman, Leonard Saul. 1998. The Process of Ratemaking. Public Utilities Reports.

Grandy, Jake and Shon Hiatt. 2020. "State Agency Discretion and Entrepreneurship in Regulated Markets." Administrative Science Quarterly.

Greenwood, Royston, Mia Raynard, Farah Kodeih, Evelyn R. Micelotta, and Michael Lounsbury. 2011. "Institutional Complexity and Organizational Responses." Academy of Management Annals 5(1):317-71.

Hagerman, Robert L. and Brian T. Ratchford. 1978. "Some Determinants of Allowed Rates of Return on Equity to Electric Utilities." Bell Journal of Economics 9(1):46-55.

Heckman, James J. 1979. "Sample Selection Bias as a Specification Error." Econometrica 47(1):153-61.

Hempling, Scott. 2013. Preside or Lead? The Attributes and Actions of Effective Regulators. Silver Springs, MD.

Henisz, Witold J., Sinziana Dorobantu, and Lite J. Nartey. 2014. "Spinning Gold: The Financial Returns to Stakeholder Engagement." Strategic Management Journal 35(12):1727-1748.

Hiatt, Shon R., Jake B. Grandy, and Brandon H. Lee. 2015. "Organizational Responses to Public and Private Politics : An Analysis of Climate Change Activists and U.S. Oil and Gas Firms." Organization Science 26(6):1769-86.

Hiatt, Shon R. and Sangchan Park. 2013. "Lords of the Harvest: Third-Party Influence and Regulatory Approval of Genetically Modified Organisms." Academy of Management Journal 56(4):923-44.

Hiatt, Shon R., Wesley D. Sine, and Pamela S. Tolbert. 2009. "From Pabst to Pepsi: The Deinstitutionalization of Social Practices and the Creation of Entrepreneurial Opportunities." Administrative Science Quarterly 54(4):635-67.

Hoffman, Andrew J. and Stephanie Bertels. 2010. "Who Is Part of the Environmental Movement?" Pp. 48-70 in Good Cop/Bad Cop: Environmental NGOs and their Strategies Toward Business, edited by T. P. Lyon. RFF Press.

Holburn, Guy L. F. and Richard G. Vanden Bergh. 2006. "Consumer Capture of Regulatory Institutions: The Creation of Public Utility Consumer Advocates in the United States." Public Choice 126(1/2):45-73.

Hyman, Leonard S. 2000. America's Electric Utilities: Past, Present and Future. Arlington, VA: Public Utilities Reports.

Hyman, Leonard S. and Ernst R. Habicht. 1986. "State Electric Utility Regulation: Financial Issues, Influences, and Trends." Annual Review of Energy 11:163-85.

Ingram, Paul, Lori Qingyuan Yue, and Hayagreeva Rao. 2010. "Trouble in Store: Probes, Protests, and Store Openings by Wal-Mart, 1998 - 2007.” American Journal of Sociology 116(1):53-92.

Joskow, Paul L. 1974. "Inflation and Environmental Concern: Structural Change in the Process of Public Utility Price Regulation." Journal of Law and Economics 17(2):291-327.

Joskow, Paul L. 2006. "Markets for Power in the United States: An Interim Assessment." Energy Journal 27(1):1-36.

Julian, Scott D., Joseph C. Ofori-Dankwa, and Robert T. Justis. 2008. "Understanding Strategic Responses to Interest Group Pressures.” Strategic Management Journal 29(9):963-84.

Kassinis, George and Nikos Vafeas. 2006. "Stakeholder Pressures and Environmental Performance." Academy of Management Journal 49(1):145-59.

Kim, Eun Hee and Thomas P. Lyon. 2015. "Greenwash vs. Brownwash: Exaggeration and Undue Modesty in Corporate Sustainability Disclosure." Organization Science 26(3):705-23.

King, Brayden G. 2008. "A Political Mediation Model of Corporate Response to Social Movement Activism.” Administrative Science Quarterly 53(3):395-421.

King, Brayden G. and Sarah A. Soule. 2007. "Social Movements as Extra-Institutional Entrepreneurs: The Effect of Protests on Stock Price Returns." Administrative Science Quarterly 52(3):413-42.

Kitschelt, Herbert P. 1986. "Political Opportunity Structures and Political Protest: Anti-Nuclear Movements in Four Democracies." British Journal of Political Science 16(1):57-85.

Komanoff, Charles. 1982. Power Plant Cost Escalation: Nuclear and Coal Capital Cost, Regulation, and 
Economics. Van Nostrand Reinhold.

Kriesi, Hanspeter. 1989. "The Political Opportunity Structure of the Dutch Peace Movement." West European Politics 12(3):295-312.

Kriesi, Hanspeter. 2007. "Political Context and Opportunity." Pp. 67-90 in The Blackwell Companion to Social Movements, edited by D. A. Snow, S. A. Soule, and H. Kriesi. Blackwell.

Lammers, Cornelius J. 1969. "Strikes and Mutinies: A Comparative Study of Organizational Conflicts between Rulers and Ruled." Administrative Science Quarterly 14(4):558-72.

Leaver, Clare. 2009. "Bureaucratic Minimal Squawk Behavior: Theory and Evidence from Regulatory Agencies." American Economic Review 99(3):572-607.

Lesser, Jonathan A. 2002. "The Used and Useful Test: Implications for a Restructured Electric Industry." Energy Law Journal 23(1):349-82.

Levy, Brian and Pablo T. Spiller. 1994. "The Institutional Foundations of Regulatory Commitment : A Comparative Analysis of Telecommunications Regulation.” Journal of Law, Economics, \& Organization 10(2):201-46.

Lohmann, Susanne. 1993. "A Signaling Model of Informative and Manipulative Political Action." American Political Science Review 87(2):319-33.

Luders, Joseph. 2006. "The Economics of Movement Success: Business Responses to Civil Rights Mobilization." American Journal of Sociology 111(4):963-98.

Luo, Xiaowei R., Jianjun Zhang, and Christopher Marquis. 2016. "Mobilization in the Internet Age: Internet Activism and Corporate Response." Academy of Management Journal 59(1):2045-2068.

Luo, Xueming and C. B. Bhattacharya. 2006. "Corporate Social Responsibility, Customer Satisfaction, and Market Value." Journal of Marketing 70(4):1-18.

Lyon, Thomas P. 2010. Good Cop/Bad Cop: Environmental NGOs and Their Strategies towards Business. Washington, DC: RFF Press.

Lyon, Thomas P. and John W. Mayo. 2005. "Regulatory Opportunism and Investment Behavior: Evidence from the U.S. Electric Utility Industry." RAND Journal of Economics 36(3):628-44.

Lyon, Thomas P. and Haitao Yin. 2010. "Why Do States Adopt Renewable Portfolio Standards?: An Empirical Investigation." Energy Journal 31(3):133-58.

Macher, Jeffrey T., John W. Mayo, and Jack A. Nickerson. 2011. "Regulator Heterogeneity and Endogenous Efforts to Close the Information Asymmetry." Journal of Law and Economics 54(1):25-54.

McCubbins, Mathew D., Roger G. Noll, and Barry R. Weingast. 1987. "Administrative Procedures as Instruments of Political Control." Journal of Law, Economics, \& Organization 3(2):243-77.

McDonnell, Mary-Hunter. 2016. "Radical Repertoires: The Incidence and Impact of Corporate-Sponsored Social Activism." Organization Science.

McDonnell, Mary-Hunter and Brayden G. King. 2013. "Keeping up Appearances: Reputational Threat and Impression Management after Social Movement Boycotts." Administrative Science Quarterly 58(3):387-419.

McDonnell, Mary-Hunter and Timothy Werner. 2016. Blacklisted Businesses: Social Activists' Challenges and the Disruption of Corporate Political Activity. Vol. 61.

Miles, Robert H. and Arvind Bhambri. 1983. The Regulatory Executives. SAGE.

Nelkin, Dorothy. 1981. "Some Social and Political Dimensions of Nuclear Power: Examples from Three Mile Island." The American Political Science Review 75(1):132-42.

Newig, Jens. 2004. "Public Attention, Political Action: The Example of Environmental Regulation." Rationality and Society 16(2):149-90.

Newton, Casey. 2018. "Facebook's Morale Problem Is Getting Worse.” The Verge, December 6.

Park, Brian and Michelle Rogan. 2019. "Capability Reputation, Character Reputation, and Exchange Partners' Reactions to Adverse Events." Academy of Management Journal 62(2):553-78.

Peltzman, Sam. 1976. "Toward a More General Theory of Regulation.” The Journal of Law \& Economics 19(2):211-40.

Piazza, Alessandro and Fabrizio Perretti. 2015. "Categorical Stigma and Firm Disengagement: Nuclear 
Power Generation in the United States, 1970-2000." Organization Science 26(3):724-42.

Piazza, Alessandro and Fabrizio Perretti. 2020. "Firm Behavior and the Evolution of Activism: Strategic Decisions and the Emergence of Protest in US Communities." Strategic Management Journal 41(4):681-707.

Piazza, Alessandro and Dan J. Wang. 2020. "Claim Specialization, Tactical Diversity and the Role of the Protest Environment in Protest Success: Evidence from Anti-Nuclear Activism in the United States." Mobilization 25(1):93-114.

Piven, Frances Fox and Richard A. Cloward. 1977. Poor People's Movements: Why They Succeed, How They Fail. New York, NY: Vintage Books.

Poole, Keith T. and Howard Rosenthal. 1985. "A Spatial Model for Legislative Roll Call Analysis." American Journal of Political Science 29(2):357-84.

Reid, Erin M. and Michael W. Toffel. 2009. "Responding to Public and Private Politics: Corporate Disclosure of Climate Change Strategies." Strategic Management Journal 30(June):1157-78.

Roberts, Peter W. and Grahame R. Dowling. 2002. "Corporate Reputation and Sustained Superior Financial Performance.” Strategic Management Journal 23(12):1077-93.

Roberts, R. Blaine, G. S. Maddala, and Gregory Enholm. 1978. "Determinants of the Requested Rate of Return and the Rate of Return Granted in a Formal Regulatory Process." Bell Journal of Economics 9(2):611.

Rochon, Thomas R. and Daniel A. Mazmanian. 1993. "Social Movements and the Policy Process." The Annals of the American Academy of Political and Social Science 528(1):75-87.

Rodriguez, Salvador. 2019. "Facebook Has Struggled to Recruit since Cambridge Analytica Scandal." $C N B C$, May 16.

Ross, Jerry and Barry M. Staw. 1993. "Organizational Escalation and Exit: Lessons from the Shoreham Nuclear Power Plant.” Academy of Management Journal 36(4):701-32.

Rucht, Dieter. 1990. "Campaigns, Skirmishes and Battles: Anti-Nuclear Movements in the USA, France and West Germany." Organization \& Environment 4(3):193-222.

Ruf, Bernadette M., Krishnamurty Muralidhar, Robert M. Brown, Jay J. Janney, and Karen Paul. 2001. "An Empirical Investigation of the Relationship between Change in Corporate Social Performance and Financial Performance: A Stakeholder Theory Perspective." Journal of Business Ethics 32(2):143-56.

Schneiberg, Marc and Tim Bartley. 2001. "Regulating American Industries: Markets, Politics, and the Institutional Determinants of Fire Insurance Regulation." American Journal of Sociology 107(1):101-46.

Schneiberg, Marc and Sarah A. Soule. 2005. "Institutionalization as a Contested, Multilevel Process: The Case of Rate Regulation in American Fire Insurance.” Pp. 122-60 in Social Movements and Organization Theory. Cambridge University Press.

Shipan, Charles R. 2004. "Regulatory Regimes, Agency Actions, and the Conditional Nature of Congressional Influence." American Political Science Review 98(3):467-80.

Slawson, Nicola. 2018. "Faceblock Campaign Urges Users to Boycott Facebook for a Day." The Guardian, April 7.

Soule, Sarah A. and Brayden G. King. 2006. "The Stages of the Policy Process and the Equal Rights Amendment, 1972-1982.” American Journal of Sociology 111(6):1871-1909.

Soule, Sarah A. and Susan Olzak. 2004. "When Do Movements Matter? The Politics of Contingency and the Equal Rights Amendment." American Sociological Review 69(4):473-97.

Soule, Sarah A., Anand Swaminathan, and Laszlo Tihanyi. 2014. "The Diffusion of Foreign Divestment from Burma." Strategic Management Journal 35(7):1032-52.

Stigler, George J. 1971. "The Theory of Economic Regulation." Bell Journal of Economics and Management Science 2(1):3-21.

Stock, James and Motohiro Yogo. 2002. Testing for Weak Instruments in Linear IV Regression. Cambridge, MA.

Teske, Paul. 1991. "Interests and Institutions in State Regulation." American Journal of Political Science 
35(1):139-54.

Thomas, Steve. 2010. The Economics of Nuclear Power: An Update. Berlin: Heinrich Böll Foundation. Vasi, Ion Bogdan and Brayden G. King. 2012. "Social Movements, Risk Perceptions, and Economic Outcomes: The Effect of Primary and Secondary Stakeholder Activism on Firms' Perceived Environmental Risk and Financial Performance." American Sociological Review 77(4):573- 596.

Viscusi, Kip W., Joseph E. Harrington, and John M. Vernon. 2005. Economics of Regulation and Antitrust. Cambridge, MA: The MIT Press.

Walker, Edward T., Andrew W. Martin, and John D. McCarthy. 2008. "Confronting the State, the Corporation, and the Academy: The Influence of Institutional Targets on Social Movement Repertoires." American Journal of Sociology 114(1):35-76.

Walker, J. Samuel. 2006. Three Mile Island: A Nuclear Crisis in Historical Perspective. Berkeley, CA: University of California Press.

Walsh, Edward J. 1981. "Resource Mobilization and Citizen Protest in Communities around Three Mile Island." Social Problems 29(1):1-21.

Walsh, Edward J. 1986. "The Role of Target Vulnerabilities in High-Technology Protest Movements : The Nuclear Establishment at Three Mile Island." Sociological Forum 1(2):199-218.

Weingast, Barry R. and Mark J. Moran. 1983. "Bureaucratic Discretion or Congressional Control? Regulatory Policymaking by the Federal Trade Commission." Journal of Political Economy 91(5):765-800.

Welch, Francis X. 1968. Cases and Text on Public Utility Regulation. Washington, DC: Public Utilities Reports.

Wellock, Thomas. 1998. Critical Masses: Opposition to Nuclear Power in California, 1958-1978. The University of Wisconsin Press.

Wilson, Kristin and Stan Veuger. 2017. "Information Frictions in Uncertain Regulatory Environments: Evidence from U.S. Commercial Banks." Oxford Bulletin of Economics and Statistics 79(2):205-33.

Wolfolds, Sarah E. and Jordan Siegel. 2019. "Misaccounting for Endogeneity: The Peril of Relying on the Heckman Two-Step Method without a Valid Instrument.” Strategic Management Journal.

Yue, Lori Qingyuan, Hayagreeva Rao, and Paul Ingram. 2013. "Information Spillovers from Protests Against Corporations: A Tale of Walmart and Target." Administrative Science Quarterly 58(4):669701.

Zavyalova, Anastasiya, Michael D. Pfarrer, Rhonda K. Reger, and Timothy D. Hubbard. 2016.

"Reputation as a Benefit and a Burden? How Stakeholders' Organizational Identification Affects the Role of Reputation Following a Negative Event." Academy of Management Journal 59(1):253-76. 
Table 1 Descriptive Statistics and Correlation Matrix

\begin{tabular}{|c|c|c|c|c|c|c|c|c|c|c|c|c|c|c|c|c|c|c|c|c|c|c|c|c|c|c|c|}
\hline & & Mean & SD & 1 & 2 & 3 & 4 & 5 & 6 & 7 & 8 & 9 & 10 & 11 & 12 & 13 & 14 & 15 & 16 & 17 & 18 & 19 & 20 & 21 & 22 & 23 & 24 \\
\hline 1 & Rate Review & 0.343 & 0.475 & & & & & & & & & & & & & & & & & & & & & & & & \\
\hline 2 & Rate of Return & 9.893 & 1.594 & -0.13 & & & & & & & & & & & & & & & & & & & & & & & \\
\hline 3 & Protests & 2.148 & 9.039 & 0.09 & 0.16 & & & & & & & & & & & & & & & & & & & & & & \\
\hline 4 & Democratic Regulator & 0.548 & 0.278 & -0.01 & 0.01 & 0.01 & & & & & & & & & & & & & & & & & & & & & \\
\hline 5 & $\begin{array}{l}\text { Democratic Governor } \\
\text { and Legislature }\end{array}$ & 0.364 & 0.481 & 0.02 & 0.03 & 0.09 & 0.44 & & & & & & & & & & & & & & & & & & & & \\
\hline 6 & $\begin{array}{l}\text { Republican Governor } \\
\text { and Legislature }\end{array}$ & 0.120 & 0.326 & -0.04 & -0.10 & -0.03 & -0.23 & -0.28 & & & & & & & & & & & & & & & & & & & \\
\hline 7 & $\begin{array}{l}\text { Nuclear Units } \\
\text { Cancelled }\end{array}$ & 0.036 & 0.273 & 0.07 & 0.12 & 0.16 & 0.00 & 0.01 & -0.02 & & & & & & & & & & & & & & & & & & \\
\hline 8 & $\begin{array}{l}\text { Performance in prior } \\
\text { rate review }\end{array}$ & -0.018 & 0.647 & 0.02 & 0.15 & -0.01 & 0.00 & -0.02 & -0.01 & 0.03 & & & & & & & & & & & & & & & & & \\
\hline 9 & $\begin{array}{l}\text { Nuclear Proportion of } \\
\text { Plants }\end{array}$ & 0.046 & 0.099 & 0.05 & 0.09 & 0.25 & -0.04 & 0.02 & -0.04 & 0.06 & 0.03 & & & & & & & & & & & & & & & & \\
\hline 10 & $\begin{array}{l}\text { Nuclear Plants in Pre- } \\
\text { Construction Stage }\end{array}$ & 0.164 & 0.488 & 0.14 & -0.27 & 0.05 & -0.02 & 0.00 & 0.03 & 0.01 & 0.00 & 0.08 & & & & & & & & & & & & & & & \\
\hline 11 & $\begin{array}{l}\text { Nuclear Plants in } \\
\text { Construction Stage }\end{array}$ & 0.239 & 0.508 & 0.18 & 0.02 & 0.29 & 0.01 & 0.04 & -0.04 & 0.13 & 0.02 & 0.21 & 0.42 & & & & & & & & & & & & & & \\
\hline 12 & $\begin{array}{l}\text { League of } \\
\text { Conservation Voters } \\
\text { Score }\end{array}$ & 49.142 & 18.319 & 0.07 & 0.11 & 0.20 & -0.31 & -0.05 & 0.04 & 0.03 & 0.02 & 0.19 & 0.08 & 0.05 & & & & & & & & & & & & & \\
\hline 13 & Consumer Advocate & 0.446 & 0.497 & 0.01 & 0.32 & 0.14 & -0.06 & 0.05 & -0.07 & 0.03 & 0.01 & 0.19 & -0.09 & 0.02 & 0.28 & & & & & & & & & & & & \\
\hline 14 & Industrial Consumers & 37.077 & 11.804 & -0.06 & 0.00 & -0.14 & 0.12 & 0.05 & -0.06 & -0.01 & 0.01 & -0.17 & 0.02 & 0.02 & -0.40 & -0.21 & & & & & & & & & & & \\
\hline 15 & Legislature Rivalry & 0.673 & 0.252 & -0.01 & 0.00 & -0.02 & -0.39 & -0.56 & 0.15 & 0.01 & 0.04 & 0.00 & 0.03 & -0.01 & 0.24 & 0.04 & -0.17 & & & & & & & & & & \\
\hline 16 & Governor Rivalry & 0.165 & 0.371 & 0.04 & -0.02 & -0.03 & -0.05 & -0.12 & -0.01 & -0.01 & 0.03 & -0.02 & 0.05 & 0.10 & -0.13 & -0.07 & 0.11 & 0.15 & & & & & & & & & \\
\hline 17 & Regulator Experience & 3.883 & 2.935 & -0.06 & -0.16 & -0.06 & 0.14 & 0.01 & -0.02 & -0.06 & -0.04 & 0.00 & -0.02 & -0.02 & -0.23 & -0.16 & 0.10 & -0.15 & -0.11 & & & & & & & & \\
\hline 18 & $\begin{array}{l}\text { Change in Per Capita } \\
\text { Income }\end{array}$ & 0.728 & 0.035 & 0.14 & -0.19 & 0.16 & 0.12 & 0.10 & -0.03 & 0.06 & 0.00 & -0.06 & 0.18 & 0.17 & -0.06 & -0.20 & 0.09 & -0.16 & 0.07 & -0.05 & & & & & & & \\
\hline 19 & $\begin{array}{l}\text { Change in Interest } \\
\text { Rate }\end{array}$ & 7.885 & 32.907 & 0.09 & -0.31 & 0.03 & 0.04 & 0.00 & 0.09 & 0.01 & 0.03 & -0.11 & 0.08 & 0.04 & -0.10 & -0.29 & 0.15 & -0.10 & 0.05 & 0.00 & 0.40 & & & & & & \\
\hline 20 & Change in Fuel Cost & 22.415 & 67.936 & 0.08 & -0.16 & 0.00 & 0.13 & 0.05 & -0.02 & -0.01 & 0.00 & -0.10 & 0.10 & 0.02 & -0.14 & -0.22 & 0.17 & -0.14 & 0.07 & -0.05 & 0.26 & 0.55 & & & & & \\
\hline 21 & Average Fuel Cost & 1.384 & 0.868 & 0.06 & 0.57 & 0.24 & 0.01 & 0.12 & -0.15 & 0.08 & 0.01 & 0.07 & -0.13 & 0.06 & 0.20 & 0.28 & -0.21 & -0.11 & 0.01 & -0.15 & -0.07 & -0.22 & -0.02 & & & & \\
\hline 22 & Elected PUC & 0.144 & 0.351 & -0.07 & -0.05 & -0.05 & 0.25 & 0.08 & 0.07 & -0.02 & -0.02 & -0.12 & -0.06 & -0.04 & -0.30 & -0.17 & 0.13 & -0.21 & -0.07 & 0.38 & 0.01 & -0.01 & 0.01 & -0.12 & & & \\
\hline 23 & Market Share & 0.245 & 0.257 & 0.09 & 0.02 & 0.12 & 0.10 & 0.05 & -0.01 & 0.05 & 0.01 & 0.03 & 0.10 & 0.20 & -0.08 & -0.04 & -0.01 & -0.06 & -0.07 & 0.13 & 0.00 & -0.07 & -0.08 & 0.00 & 0.19 & & \\
\hline 24 & $\begin{array}{l}\text { Other Firms' Rate } \\
\text { Reviews }\end{array}$ & 0.667 & 0.471 & 0.19 & -0.01 & 0.06 & -0.08 & 0.02 & -0.05 & 0.05 & 0.02 & 0.01 & 0.12 & 0.14 & 0.16 & 0.04 & -0.05 & 0.01 & 0.09 & -0.17 & 0.16 & 0.12 & 0.10 & 0.06 & -0.20 & -0.27 & \\
\hline 25 & $\begin{array}{l}\text { Change in Electricity } \\
\text { Consumption }\end{array}$ & 0.034 & 0.417 & -0.04 & -0.23 & -0.05 & 0.13 & 0.11 & 0.03 & -0.02 & -0.02 & -0.05 & 0.02 & 0.00 & -0.13 & -0.17 & 0.04 & -0.10 & -0.01 & 0.06 & 0.22 & 0.16 & 0.05 & -0.22 & 0.06 & 0.03 & -0.04 \\
\hline
\end{tabular}


Table 2 Heckman Two-Stage Regression Models of Impact of Protests on Regulated Rate of Return

\begin{tabular}{|c|c|c|c|c|c|c|}
\hline & $\begin{array}{l}\text { Model } 1 \\
\text { Rate } \\
\text { Review }\end{array}$ & $\begin{array}{l}\text { Model 2a } \\
\text { Rate of } \\
\text { Return }\end{array}$ & $\begin{array}{l}\text { Model 2b } \\
\text { Rate of } \\
\text { Return }\end{array}$ & $\begin{array}{l}\text { Model 2c } \\
\text { Rate of } \\
\text { Return }\end{array}$ & $\begin{array}{l}\text { Model 2d } \\
\text { Rate of } \\
\text { Return }\end{array}$ & $\begin{array}{l}\text { Model 2e } \\
\text { Rate of } \\
\text { Return }\end{array}$ \\
\hline Protests $(\mathrm{H} 1)$ & $\begin{array}{l}-0.005^{* *} \\
(0.002)\end{array}$ & $\begin{array}{l}-0.005^{* *} \\
(0.002)\end{array}$ & $\begin{array}{l}-0.002 \\
(0.003)\end{array}$ & $\begin{array}{l}0.006^{* *} \\
(0.003)\end{array}$ & $\begin{array}{l}-0.005^{* *} \\
(0.002)\end{array}$ & $\begin{array}{l}-0.006 * * \\
(0.003)\end{array}$ \\
\hline Democratic Regulator & $\begin{array}{l}-0.152 \\
(0.138)\end{array}$ & $\begin{array}{l}-0.097 \\
(0.108)\end{array}$ & $\begin{array}{l}-0.089 \\
(0.108)\end{array}$ & $\begin{array}{l}-0.082 \\
(0.108)\end{array}$ & $\begin{array}{l}-0.097 \\
(0.108)\end{array}$ & $\begin{array}{l}-0.095 \\
(0.108)\end{array}$ \\
\hline Democratic Governor and Legislature & $\begin{array}{l}-0.085 \\
(0.064)\end{array}$ & $\begin{array}{l}-0.157^{* * *} \\
(0.054)\end{array}$ & $\begin{array}{l}-0.153 * * * \\
(0.056)\end{array}$ & $\begin{array}{l}-0.153 * * \\
(0.055)\end{array}$ & $\begin{array}{l}-0.157^{* * *} \\
(0.056)\end{array}$ & $\begin{array}{l}-0.161 * * * \\
(0.057)\end{array}$ \\
\hline Republican Governor and Legislature & $\begin{array}{l}-0.095 \\
(0.108)\end{array}$ & $\begin{array}{l}0.084 \\
(0.125)\end{array}$ & $\begin{array}{l}0.084 \\
(0.124)\end{array}$ & $\begin{array}{l}0.083 \\
(0.124)\end{array}$ & $\begin{array}{l}0.085 \\
(0.125)\end{array}$ & $\begin{array}{l}0.085 \\
(0.125)\end{array}$ \\
\hline Nuclear Units Cancelled & $\begin{array}{l}0.062 \\
(0.070)\end{array}$ & $\begin{array}{l}0.109^{* *} \\
(0.044)\end{array}$ & $\begin{array}{l}0.111^{* *} \\
(0.044)\end{array}$ & $\begin{array}{l}0.105^{* *} \\
(0.045)\end{array}$ & $\begin{array}{l}0.109 * * \\
(0.044)\end{array}$ & $\begin{array}{l}0.097 * * \\
(0.046)\end{array}$ \\
\hline Performance in Prior Rate Review & $\begin{array}{l}-0.021 \\
(0.035)\end{array}$ & $\begin{array}{l}0.288^{* * *} \\
(0.051)\end{array}$ & $\begin{array}{l}0.287 * * * \\
(0.051)\end{array}$ & $\begin{array}{l}0.288^{* * *} \\
(0.050)\end{array}$ & $\begin{array}{l}0.289 * * * \\
(0.050)\end{array}$ & $\begin{array}{l}0.289 * * * \\
(0.051)\end{array}$ \\
\hline $\begin{array}{l}\text { Protests * Democratic Governor and } \\
\text { Legislature (H2) }\end{array}$ & & & $\begin{array}{l}-0.007 * * \\
(0.003)\end{array}$ & & & \\
\hline Protests * Democratic Regulator $(\mathrm{H} 3)$ & & & & $\begin{array}{l}-0.018 * * * \\
(0.005)\end{array}$ & & \\
\hline $\begin{array}{l}\text { Protests * Performance in Prior Rate } \\
\text { Review (H4) }\end{array}$ & & & & & $\begin{array}{l}0.006^{* * *} \\
(0.002)\end{array}$ & \\
\hline Protests * Nuclear Units Cancelled (H5) & & & & & & $\begin{array}{l}0.003^{* *} \\
(0.001)\end{array}$ \\
\hline Nuclear Proportion of Plants & $\begin{array}{l}0.390 \\
(0.447)\end{array}$ & $\begin{array}{l}1.663 * * * \\
(0.612)\end{array}$ & $\begin{array}{l}1.669^{* * *} \\
(0.609)\end{array}$ & $\begin{array}{l}1.615^{* * *} \\
(0.618)\end{array}$ & $\begin{array}{l}1.663 * * * \\
(0.612)\end{array}$ & $\begin{array}{l}1.660^{* * *} \\
(0.613)\end{array}$ \\
\hline Nuclear Plants in Pre-Construction Stage & $\begin{array}{l}-0.066 \\
(0.062)\end{array}$ & $\begin{array}{l}-0.179^{* * *} \\
(0.058)\end{array}$ & $\begin{array}{l}-0.178^{* * *} \\
(0.058)\end{array}$ & $\begin{array}{l}-0.172 * * * \\
(0.058)\end{array}$ & $\begin{array}{l}-0.179^{* * *} \\
(0.059)\end{array}$ & $\begin{array}{l}-0.179^{* * *} \\
(0.058)\end{array}$ \\
\hline Nuclear Plants in Construction Stage & $\begin{array}{l}0.118^{* *} \\
(0.059)\end{array}$ & $\begin{array}{l}0.337 * * * \\
(0.057)\end{array}$ & $\begin{array}{l}0.339 * * * \\
(0.057)\end{array}$ & $\begin{array}{l}0.336^{* * *} \\
(0.056)\end{array}$ & $\begin{array}{l}0.337 * * * \\
(0.058)\end{array}$ & $\begin{array}{l}0.336 * * * \\
(0.058)\end{array}$ \\
\hline League of Conservation Voters Score & $\begin{array}{l}0.003 \\
(0.002)\end{array}$ & $\begin{array}{l}-0.022 * * \\
(0.012)\end{array}$ & $\begin{array}{l}-0.021 * * \\
(0.013)\end{array}$ & $\begin{array}{l}-0.019 * * \\
(0.009)\end{array}$ & $\begin{array}{l}-0.024 * * \\
(0.010)\end{array}$ & $\begin{array}{l}-0.022 * * \\
(0.010)\end{array}$ \\
\hline Consumer Advocate & $\begin{array}{l}0.063 \\
(0.086)\end{array}$ & $\begin{array}{l}0.161 \\
(0.151)\end{array}$ & $\begin{array}{l}0.165 \\
(0.157)\end{array}$ & $\begin{array}{l}0.165 \\
(0.161)\end{array}$ & $\begin{array}{l}0.160 \\
(0.151)\end{array}$ & $\begin{array}{l}0.160 \\
(0.153)\end{array}$ \\
\hline Industrial Consumers & $\begin{array}{l}0.002 \\
(0.009)\end{array}$ & $\begin{array}{l}-0.007 \\
(0.009)\end{array}$ & $\begin{array}{l}-0.007 \\
(0.009)\end{array}$ & $\begin{array}{l}-0.007 \\
(0.009)\end{array}$ & $\begin{array}{l}-0.006 \\
(0.008)\end{array}$ & $\begin{array}{l}-0.006 \\
(0.009)\end{array}$ \\
\hline Legislature Rivalry & $\begin{array}{l}-0.413 * \\
(0.243)\end{array}$ & $\begin{array}{l}-0.497 * * \\
(0.221)\end{array}$ & $\begin{array}{l}-0.505^{* *} \\
(0.220)\end{array}$ & $\begin{array}{l}-0.504 * * \\
(0.219)\end{array}$ & $\begin{array}{l}-0.497^{* *} \\
(0.221)\end{array}$ & $\begin{array}{l}-0.492 * * \\
(0.221)\end{array}$ \\
\hline Governor Rivalry & $\begin{array}{l}0.080 \\
(0.062)\end{array}$ & $\begin{array}{l}0.049 \\
(0.073)\end{array}$ & $\begin{array}{l}0.047 \\
(0.073)\end{array}$ & $\begin{array}{l}0.048 \\
(0.072)\end{array}$ & $\begin{array}{l}0.049 \\
(0.073)\end{array}$ & $\begin{array}{l}0.048 \\
(0.073)\end{array}$ \\
\hline Regulator Experience & $\begin{array}{l}0.009 \\
(0.012)\end{array}$ & $\begin{array}{l}-0.001 \\
(0.012)\end{array}$ & $\begin{array}{l}-0.004 \\
(0.012)\end{array}$ & $\begin{array}{l}-0.004 \\
(0.014)\end{array}$ & $\begin{array}{l}-0.002 \\
(0.012)\end{array}$ & $\begin{array}{l}-0.002 \\
(0.012)\end{array}$ \\
\hline Change in Per Capita Income & $\begin{array}{l}-1.863 * \\
(1.120)\end{array}$ & $\begin{array}{l}0.256 \\
(0.791)\end{array}$ & $\begin{array}{l}0.320 \\
(0.823)\end{array}$ & $\begin{array}{l}0.291 \\
(0.797)\end{array}$ & $\begin{array}{l}0.297 \\
(0.789)\end{array}$ & $\begin{array}{l}0.287 \\
(0.778)\end{array}$ \\
\hline Change in Interest Rate & $\begin{array}{l}0.003 * * \\
(0.001)\end{array}$ & $\begin{array}{l}0.001 \\
(0.002)\end{array}$ & $\begin{array}{l}0.001 \\
(0.001)\end{array}$ & $\begin{array}{l}0.001 \\
(0.002)\end{array}$ & $\begin{array}{l}0.001 \\
(0.002)\end{array}$ & $\begin{array}{l}0.002 \\
(0.002)\end{array}$ \\
\hline Change in Fuel Cost & $\begin{array}{l}0.002 * * * \\
(0.001)\end{array}$ & $\begin{array}{l}0.001^{*} \\
(0.001)\end{array}$ & $\begin{array}{l}0.002 * * \\
(0.001)\end{array}$ & $\begin{array}{l}0.002 * * \\
(0.001)\end{array}$ & $\begin{array}{l}0.002 * * \\
(0.001)\end{array}$ & $\begin{array}{l}0.002 * * \\
(0.001)\end{array}$ \\
\hline Average Fuel Cost & $\begin{array}{l}-0.128^{* * *} \\
(0.048)\end{array}$ & $\begin{array}{l}0.022 \\
(0.059)\end{array}$ & $\begin{array}{l}0.029 \\
(0.058)\end{array}$ & $\begin{array}{l}0.036 \\
(0.058)\end{array}$ & $\begin{array}{l}0.028 \\
(0.059)\end{array}$ & $\begin{array}{l}0.027 \\
(0.059)\end{array}$ \\
\hline Elected PUC & $\begin{array}{l}-0.173 \\
(0.129)\end{array}$ & $\begin{array}{l}-0.759 \\
(0.643)\end{array}$ & $\begin{array}{l}-0.739 \\
(0.657)\end{array}$ & $\begin{array}{l}-0.745 \\
(0.655)\end{array}$ & $\begin{array}{l}-0.719 \\
(0.657)\end{array}$ & $\begin{array}{l}-0.746 \\
(0.665)\end{array}$ \\
\hline Market Share & $\begin{array}{l}1.349 \\
(1.026)\end{array}$ & $\begin{array}{l}2.295^{* *} \\
(1.022)\end{array}$ & $\begin{array}{l}2.192 * * \\
(1.039)\end{array}$ & $\begin{array}{l}2.229^{* *} \\
(1.041)\end{array}$ & $\begin{array}{l}2.307^{* *} \\
(1.021)\end{array}$ & $\begin{array}{l}2.337^{* *} \\
(0.979)\end{array}$ \\
\hline Other Firms' Rate Reviews & $\begin{array}{l}0.214 * * * \\
(0.062)\end{array}$ & $\begin{array}{l}0.289 \\
(0.195)\end{array}$ & $\begin{array}{l}0.288 \\
(0.199)\end{array}$ & $\begin{array}{l}0.280 \\
(0.196)\end{array}$ & $\begin{array}{l}0.288 \\
(0.194)\end{array}$ & $\begin{array}{l}0.293 \\
(0.192)\end{array}$ \\
\hline $\begin{array}{l}\text { Change in Electricity Consumption in } \\
\text { State }\end{array}$ & $\begin{array}{l}0.471 \\
(0.696)\end{array}$ & & & & & \\
\hline Inverse Mills Ratio & & $\begin{array}{l}1.694 * * * \\
(0.444)\end{array}$ & $\begin{array}{l}1.683 * * * \\
(0.441)\end{array}$ & $\begin{array}{l}1.645^{* * *} \\
(0.444)\end{array}$ & $\begin{array}{l}1.694 * * * \\
(0.445)\end{array}$ & $\begin{array}{l}1.258 * * * \\
(0.432)\end{array}$ \\
\hline Constant & $\begin{array}{l}-3.241^{* * *} \\
(1.224)\end{array}$ & $\begin{array}{l}-0.621 \\
(1.790) \\
\end{array}$ & $\begin{array}{l}6.642^{* * *} \\
(0.753) \\
\end{array}$ & $\begin{array}{l}2.810^{* *} \\
(1.428) \\
\end{array}$ & $\begin{array}{l}-0.633 \\
(1.790) \\
\end{array}$ & $\begin{array}{l}4.700^{* * * *} \\
(1.392)\end{array}$ \\
\hline $\begin{array}{l}\text { Year Fixed Effects } \\
\text { Firm Fixed Effects }\end{array}$ & $\begin{array}{l}\text { Yes } \\
\text { Yes }\end{array}$ & $\begin{array}{l}\text { Yes } \\
\text { Yes } \\
\end{array}$ & $\begin{array}{l}\text { Yes } \\
\text { Yes }\end{array}$ & $\begin{array}{l}\text { Yes } \\
\text { Yes }\end{array}$ & $\begin{array}{l}\text { Yes } \\
\text { Yes }\end{array}$ & $\begin{array}{l}\text { Yes } \\
\text { Yes }\end{array}$ \\
\hline $\begin{array}{l}\text { Observations } \\
\text { R-Squared }\end{array}$ & $\begin{array}{l}4351 \\
0.190\end{array}$ & $\begin{array}{l}1680 \\
0.859\end{array}$ & $\begin{array}{l}1680 \\
0.859\end{array}$ & $\begin{array}{l}1680 \\
0.859\end{array}$ & $\begin{array}{l}1680 \\
0.859\end{array}$ & $\begin{array}{l}1680 \\
0.859\end{array}$ \\
\hline
\end{tabular}


Table 3a Marginal Impact of Protests on Regulated Rate of Return, Conditional on Value of Democratic Governor and Legislature

\begin{tabular}{ll}
\hline $\begin{array}{l}\text { Democratic Governor and } \\
\text { Legislature }\end{array}$ & $\begin{array}{l}\text { Protests Coefficient } \\
\text { (Model } 2 \mathrm{~b} \text { ) }\end{array}$ \\
\hline 0 (Not Democrat controlled) & -0.001 \\
1 (Democrat controlled) & $-0.009^{* * *}$ \\
\hline
\end{tabular}

Notes: $* p<0.1 ; * * p<0.05 ; * * * p<0.01$.

Table 3b Marginal Impact of Protests on Regulated Rate of Return, Conditional on Value of Democratic Regulator

\begin{tabular}{ll}
\hline Democratic Regulator & $\begin{array}{l}\text { Protests Coefficient } \\
\text { (Model 2c) }\end{array}$ \\
\hline $0 \%$ & $0.006^{*}$ \\
$10 \%$ & 0.004 \\
$20 \%$ & 0.002 \\
$30 \%$ & 0.000 \\
$40 \%$ & -0.002 \\
$50 \%$ & $-0.004^{*}$ \\
$60 \%$ & $-0.005^{* * *}$ \\
$70 \%$ & $-0.007^{* * *}$ \\
$80 \%$ & $-0.009^{* * *}$ \\
$90 \%$ & $-0.011^{* * *}$ \\
$100 \%$ & $-0.013^{* * *}$ \\
\hline Notes: ${ }^{*} p<0.1 ; * * p<0.05 ; * * * p<0.01$.
\end{tabular}

Table 3c Marginal Impact of Protests on Regulated Rate of Return, Conditional on Value of Performance in Prior Rate Review

\begin{tabular}{ll}
\hline $\begin{array}{l}\text { Performance in Prior Rate } \\
\text { Review }\end{array}$ & $\begin{array}{l}\text { Protests Coefficient } \\
\text { (Model 2d) }\end{array}$ \\
\hline Min & -0.028 \\
Mean -2SD & $-0.013^{* * *}$ \\
Mean -1SD & $-0.009^{* * *}$ \\
Mean & $-0.005^{* *}$ \\
Mean +1SD & $-0.001^{* *}$ \\
Mean +2 SD & 0.003 \\
Max & 0.014 \\
\hline Notes: $* p<0.1 ; * *<<0.05 ; * * *<0.01$.
\end{tabular}

Table 3d Marginal Impact of Protests on Regulated Rate of Return, Conditional on Value of Nuclear Units Cancelled

\begin{tabular}{ll}
\hline $\begin{array}{l}\text { Nuclear Units } \\
\text { Cancelled }\end{array}$ & $\begin{array}{l}\text { Protests Coefficient } \\
\text { (Model 2e) }\end{array}$ \\
\hline 0 & $-0.006^{* * *}$ \\
1 & $-0.003^{* *}$ \\
2 & $0.000^{* *}$ \\
3 & $0.002^{* *}$ \\
4 & $0.006^{* * *}$ \\
\hline Notes: $* p<0.1 ; * * p<0.05 ; * * * p<0.01$.
\end{tabular}

